\title{
The morality of security: A theory of just securitisation
}

\author{
Symposium
}

(Received 15 October 2021; accepted 10 December 2021)

\section{Symposium introduction}

Rita Floyd

Not just securitisation: On the limits of limiting security practices Ian Loader

White supremacy as an existential threat: A response to Rita Floyd's The Morality of Security: A Theory of Just Securitization

Jessica Wolfendale

Just securitisation and transnational counterterrorism

Fiona de Londras

Not necessarily securitisation, not completely security: Locating 'just securitisation theory' in the logics of security

Paul Roe

The morality of security: A reply to critics and where to from here

Rita Floyd

\section{Symposium introduction}

\author{
Rita Floyd ${ }^{*}$ \\ Department of Political Science and International Studies, University of Birmingham, United Kingdom \\ ${ }^{*}$ Corresponding author. Email: r.floyd@bham.ac.uk
}

The purpose of this introduction is to concisely present The Morality of Security: A Theory of Just Securitization $^{1}$ so that those unfamiliar with this work are better able to engage with the symposium. The book develops a Theory of Just Securitisation outlining when securitisation is morally permissible. ${ }^{2}$ Securitisation, here, refers to more than a securitising speech act coupled with a legitimising audience's tacit or actual acceptance of the threat and defence framing. Arguably the question of the morality of securitisation is most pertinent when the same encompasses the use of measures

\footnotetext{
${ }^{1}$ Rita Floyd, The Morality of Security: A Theory of Just Securitization (Cambridge, UK: Cambridge University Press, 2019).

${ }^{2}$ Throughout the book I refer to my version by the capital letters Just Securitization Theory (for short JST); to be sure, alternative versions of a theory of just securitisation are not only possible but desirable. See Rita Floyd, 'The promise of theories of just securitisation', in Jonna Nyman and Anthony Burke (eds), Ethical Security Studies (Abingdon, UK: Routledge, 2016), pp. 75-88.

(C) The Author(s), 2022. Published by Cambridge University Press on behalf of the British International Studies Association. This is an Open Access article, distributed under the terms of the Creative Commons Attribution licence (https://creativecommons.org/licenses/by/4.0/), which permits unrestricted re-use, distribution, and reproduction in any medium, provided the original work is properly cited.
} 
and conduct that most reasonable persons would ordinarily (that is, in times when there is no relevant threat) consider unacceptable, largely because of the harm and/or the violence risked or entailed.

This research started from the twin observations that: (1) it seems reasonable to hold that the use of extraordinary emergency measures is at least sometimes morally permissible (for example, when human beings are faced with a pervasive and highly lethal infectious disease). And (2) that we - as a discipline - do not have a systematic normative theory that enables us to distinguish between securitisations that are morally justifiable, and those that are not. The bulk of the literature on ethics and security is split between scholars who, with a view to its many adverse consequences, including for putative beneficiaries, have a negative view of securitisation, preferring ceteris paribus desecuritisation. While those whose view of security is more positive tend to focus on the - undoubtedly desirable condition of being secure and not (or not so much) on exceptional, often forcible, security practice. ${ }^{3}$

Just securitisation theory (JST) takes the form of principles/criteria that designate when securitisation is morally permissible. JST is about curtailing the occurrence and destructiveness of securitisation. The substantive criteria are developed using a reflective approach inspired by analytical philosophy's method of reflective equilibrium. Central to this is the just war tradition (JWT). Although war and securitisation are distinct concepts, they are similar insofar as both involve extraordinary measures. Moreover, the JWT, - contra some critical security/International Relations scholars - has for centuries aimed to limit the possibility and destructiveness of war. ${ }^{4}$ The JWT is authoritative on the question of the morality of war, in part, because it is simultaneously a product of, and an exercise in, intersubjective learning that spans countless generations and places. ${ }^{5}$

Like recent versions of just war theory, JST is divided into three sections. The just initiation of securitisation is concerned with the move from politicisation to securitisation, and as such informed by jus ad bellum criteria, which cover 'the transition from a state of peace to a state of war'. ${ }^{6}$ Just initiation of securitisation consists of the following five criteria.

1. Just reason: There must be an objective existential threat to a referent object, that is to say a danger that - with a sufficiently high probability - threatens the survival or the essential character/properties of either a political or social order, an ecosystem, a non-human species, or individuals.

2. Just referent: Referent objects are entitled to defend themselves or are eligible for defensive assistance if they are morally justifiable. Referent objects are morally justifiable if they meet basic human needs, defined here as necessary components of human well-being. Political and social orders need to satisfy a minimum level of basic human needs ${ }^{7}$ of people part of or contained within that order and they must respect the human needs of outsiders. Ecosystems and non-human species, in turn, need to make a contribution to the human needs of a sufficiently large group of people. Human beings are justifiable referent objects

\footnotetext{
${ }^{3}$ See Columba Peoples, 'Security after emancipation? Critical theory, violence and resistance', Review of International Studies (2011), pp. 1113-35; see Jonathan Herington, 'Liberty, fear and the state: Philosophical perspectives on security', in Philippe Bourbeau (ed.), Security: Dialogue Across Disciplines (Cambridge, UK: Cambridge University Press, 2015), for these distinct understandings of security.

${ }^{4}$ Nicholas J. Rengger, Just War and International Order: The Uncivil Condition in World Politics (Cambridge, UK: Cambridge University Press, 2013), p. 9; Brian Orend, The Morality of War (Peterborough, Canada: Broadview Press, 2006), p. 31

${ }^{5}$ Cian O'Driscoll and Anthony F. Lang Jr, 'The just war tradition and the practice of political authority', in Cian O'Driscoll, Anthony F. Lang Jr, and John Williams (eds), Just War: Authority, Tradition, and Practice (Washington, DC: Georgetown University Press, 2003), pp. 1-16.

${ }^{6}$ David Rodin, 'Two emerging issues of jus post bellum: War termination and the liability of soldiers for crimes of aggression', in Carsten Stahn and Jann K. Kleffner (eds), Jus Post Bellum: Towards a Law of Transition from Conflict to Peace (The Hague: Asser, 2008), pp. 53-75 (p. 54).

${ }^{7}$ This means, for instance, that were states are concerned, only democratic states can be just referent objects because only such states protect the basic human need of autonomy. See Rita Floyd, 'States, last resort, and the obligation to securitize', Polity, 51:2 (2019), pp. 378-94 (p. 107).
} 
by virtue of being intrinsically valuable; all other referent objects therefore have instrumental value derived from the need of human beings. ${ }^{8}$

3. Right intention: The right intention for securitisation is the just cause. Securitising actors must be sincere in their intention to protect the referent object they themselves identified and declared.

4. Proportionality: The expected good gained from securitisation must be greater than the expected harm from securitisation, where the only relevant good is the good specified in the just cause.

5. Chances of success: Securitisation must have a reasonable chance of success, whereby the chances of achieving the just cause must be judged greater than those of [less harmful] alternatives to securitising.

Some readers will recoil at the mention of real threats, and by extension query the metatheoretical compatibility of just war theory - which does not question the epistemological accessibility of real threats - and securitisation theory. Undoubtedly, securitisation theory is about threat construction. However, even an overriding interest in threat construction does not necessarily rest on an outright rejection of real threats. ${ }^{9}$ This is important. Certainly, only real threats can justify the kind of rule breaking that is characteristic of successful securitisation. To be clear, in JST, the existence of a just cause does not by itself render securitisation morally permissible. Still, just cause enjoys a privileged position in so far as none of the other criteria can 'be satisfied, even in principle, unless just cause is satisfied'. ${ }^{10}$

In accordance with JST, when the five criteria listed above are satisfied, then resort to securitisation is justified. Importantly, in this book justified does not mean that relevant actors now have a moral duty to securitise the issue. All it means is that such actors are now - from a moral point of view - permitted to securitise. ${ }^{11}$ In short, JST recognises that whether or not a real threat is securitised remains a political choice of securitising actors. ${ }^{12}$

The focus on permissibility is the reason why last resort, widely considered a pivotal requirement of the jus ad bellum, does not feature in JST. In moral philosophy it is generally accepted that judgements regarding the permissibility of self- and other-defence are yielded in the evidence-relative sense, which is to say, when the available evidence suggests that forceful defence is the best option. ${ }^{13}$ Criterion 5 of JST includes this logic. It holds that securitisation is justifiable only when the available evidence suggests that securitisation has comparatively better prospects of achieving just cause than less harmful alternatives (including politicisation). Extrapolating further, I hold that when politicisation has failed to satisfy the just cause (that is, when securitisation is the last resort), securitisation is no longer optional but obligatory. ${ }^{14}$ In short, last resort sits within the realm of the duty to securitise.

Besides last resort, legitimate authority is the other prominent jus ad bellum criterion missing from JST. It is absent because legitimate authority cannot be reconciled with the multi-actor lens provided by the Copenhagen School - and explicitly adopted by JST - whereby actors other than

\footnotetext{
${ }^{8}$ Taken together, the just reason (1) and the just referent (2) are the just cause for securitisation.

${ }^{9}$ For cases in point, see Ole Wæver, 'Politics, security, theory', Security Dialogue, 42:4-5 (2011), pp. 465-80 and Thierry Balzacq, 'A theory of securitization: Origins, core assumptions, and variants', in Thierry Balzacq (ed.), Securitization Theory: How Security Problems Emerge and Dissolve (London, UK: Routledge, 2011), pp. 1-30 (p. 13).

${ }^{10}$ Jeff McMahan, 'Just cause for war', Ethics and International Affairs, 19:3 (2005), pp. 1-21 (p. 5).

${ }^{11}$ To illustrate the difference between obligation and permissibility, consider that in the UK I am permitted to have six children if I so wish, but I am not required to have any.

${ }^{12}$ Barry Buzan, Ole Wæver, and Jaap de Wilde, Security: A New Framework for Analysis (Boulder, CO: Lynne Rienner, 1998), pp. 33-5.

${ }^{13}$ Seth Lazar, 'Necessity in self-defense and war', Philosophy \& Public Affairs, 40:1 (2012), pp. 3-44.

${ }^{14}$ Provided, of course, other relevant criteria are also satisfied. See Floyd, 'States, last resort, and the obligation to securitize'; Rita Floyd, The Duty to Secure: From Just to Mandatory Securitization (unpublished book manuscript, 2021).
} 
(legitimate) states can securitise. The conceptually wider 'representative legitimacy' put forward by some just war theorists ${ }^{15}$ in an effort to include non-state actors, in turn, is regarded as superfluous. Thus, the criteria of JST - notably the just referent object and right intention - already guard against agent-benefiting securitisation. ${ }^{16}$

The second part of JST is inspired by the jus in bello, 'which specifies the rights and obligations of actors once in the state of war. ${ }^{17}$ Just conduct in securitisation is concerned with the nature of the security measures used and the obligations and rights of executors of securitisation. Put differently, the three criteria constitutive of 'jus in securitisation' specify what practitioners of security need to consider when they carry out securitisation.

6. Proportionality: ${ }^{18}$ The security measures used must be appropriate and should aim to only address the objective existential threat that occasions securitisation.

7. Necessity: The security measures used must be judged effective in dealing with the threat. They should aim to cause, or risk, the least amount of overall harm possible; and do less harm to the referent object than would otherwise be caused if securitisation was abandoned.

8. Discrimination: Executors of securitisation must respect a limited number of relevant human rights in the execution of securitisation.

In addition to just securitisation The Morality of Security also theorises just desecuritisation. Although desecuritisation logically (that is, in time) follows on from securitisation ${ }^{19}$ I hold that the justice of desecuritisation does not define or alter the justice of a prior securitisation or vice versa. They are separate processes with distinct outcomes. Moreover, unlike securitisation, desecuritisation is - when criterion 1 (timing) of just desecuritisation (below) is satisfied - morally required of relevant actors, as no securitisation can be justified in the absence of a just cause (see above).

The criteria of just desecuritisation are informed by a mixture of jus post bellum, which specifies 'the rights and obligations of actors once they have transitioned from a state of war into a state of peace $^{20}$ and jus terminatio, 'which governs the transition' from war to peace. ${ }^{21}$ Overall, just desecuritisation identifies three criteria that specify when and how securitisation must be unmade.

1. Timing: Desecuritisation of just securitisation must occur when the initial and related new objective existential threats have been neutralised, whereas desecuritisation of unjust securitisation must occur immediately.

2. Action: Desecuritisation should ideally be publically declared and corresponding security language and security measures should be terminated with immediate effect.

3. Long-term aim: In order to avoid renewed and/or reactionary securitisation, desecuritising actors should undertake context-specific restorative measures.

The purpose of JST, and hence The Morality of Security, is threefold. First, it aims to enable scholars of security, who almost inevitably have a view on the justice of any given securitisation

\footnotetext{
${ }^{15}$ Christopher J. Finlay, Terrorism and the Right to Resist: A Theory of Just Revolutionary War (Cambridge, UK: Cambridge University Press, 2015), p. 183.

${ }^{16} \mathrm{~A}$ securitisation where the primary beneficiary of securitisation is the securitising actor as opposed to the referent object (for more detail, see Rita Floyd, Security and the Environment: Securitisation Theory and US Environmental Security Policy (Cambridge, UK: Cambridge University Press, 2010).

${ }^{17}$ Rodin, 'Two emerging issues of jus post bellum', p. 54.

${ }^{18}$ I call creation 6 and 7 proportionality and necessity for ease of differentiation; in reality both refer back to JWT's criteria of proportionality and necessity.

${ }^{19}$ See Rita Floyd, 'The function of functional actors in securitisation processes', Critical Studies on Security (2020), available at: $\{$ https://www.tandfonline.com/doi/full/10.1080/21624887.2020.1827590\}.

${ }^{20}$ Rodin, 'Two emerging issues of jus post bellum', p. 54.

${ }^{21}$ Ibid.
} 
to normatively evaluate securitisations past and present. Second, JST equips practitioners to make informed judgements on what they ought to do in relevant situations. Third, JST has the potential to empower the general public to hold relevant actors accountable for how they practise security. For the latter to become a reality, however, it is important that other scholars engage with just securitisation. A good starting point is to criticise, improve, and refine what this book started. It is here where the symposium comes in.

\section{Not just securitisation: On the limits of limiting security practices}

\section{Ian Loader}

Centre for Criminology, University of Oxford, United Kingdom and School of Social and Political Sciences, University of Melbourne, Australia

The Morality of Security ${ }^{22}$ has two connected ambitions. First and foremost, Rita Floyd sets out to place the analysis and critique of securitisation on more secure normative foundations. The book is overwhelmingly devoted to this task, to proposing and defending what Floyd calls Just Securitization Theory (JST). But, in so doing, she also intends the book to contribute to a new research agenda in the study of securitisation in particular and the morality of security in general. This project seeks to remedy what Floyd takes to be the blind spot about ethics that has long pervaded the study of security, especially in International Relations. Floyd's ambition, in this wider sense, is to lay the groundwork for what she hopes can become 'a meta-theoretical framework organizing thinking on ethics and security in general' (p. 211). In this respect, the book forms part of a recent turn to ethics in security studies. ${ }^{23}$ It also connects to parallel developments in cognate fields: in political theory on emergency politics; in law/criminology on police ethics; and, more recently, principles of preventive justice, and work in anthropology on the morality of security. ${ }^{24}$ Floyd refreshingly presents her work a vehicle for extending these discussions, the first word on just securitisation but in no sense the last word on that topic. It is in this spirit that I approach the book.

I am not an International Relations scholar. My interest in questions of in/security has come from within criminology (whatever that may mean!). As such, it has long struck me that certain parallels exist between the study of securitisation and analysis of social reactions to crime. In particular, I think that strong - unexplored - affinities can be found between securitisation and the concept of moral panic. ${ }^{25}$ The standard approach to both - episodes of securitisation, and incidents of moral panic - is what one what call empirical analysis with a critical intent. The task at hand is to locate and dissect particular securitisations/moral panics asking questions such as: what amplificatory speech acts/rhetoric is being mobilised and circulated and by whom? How

\footnotetext{
${ }^{22}$ Floyd, The Morality of Security.

${ }^{23}$ Nyman and Burke (eds), Ethical Security Studies.

${ }^{24}$ Bonnie Honig, Emergency Politics: Paradox, Law: Democracy (Princeton, NJ: Princeton University Press, 2011); John Kleinig, The Ethics of Policing (Cambridge, UK: Cambridge University Press, 1996); Andrew Ashworth and Lucia Zedner, Preventive Justice (Oxford, UK: Oxford University Press, 2014); Tereza Kuldova, and Jardar Østbø (eds), Special Issue on 'Security and Morality: Critical Anthropological Perspectives', Journal of Extreme Anthropology, 4:1 (2020).

${ }^{25}$ The concept of moral panic was originally developed by Stanley Cohen in the early 1970s to depict social reactions to Mods and Rockers gathering and clashing on British beaches on bank holiday weekends (Folk Devils and Moral Panics ( $3^{\text {rd }}$ edn, Abingdon, UK: Routledge, 2002 [orig. pub. 1972]). In the intervening decades a veritable cottage industry studying moral panics has emerged within sociological criminology. The concept has also seeped out of the academy and entered media and popular discourse. Excellent reviews of the concept and its history can be found in Cohen's Foreword to the $3^{\text {rd }}$ edition of Folk Devils and Moral Panics ('Moral Panics as Cultural Politics'), and in David Garland, 'On the concept of moral panic', Crime, Media, Culture, 4:1 (2008), pp. 9-30.
} 
is that rhetoric received? What security measures follow? Against whom are they targeted and with what effects? How and why do these episodes end? Such analysis is typically accompanied by a strong whiff of scepticism, even disapproval. The critique rests on the known risks of securitisation/panic - a threat to due process and the rule of law; the curbing of human rights; an exclusionary logic that others minority groups; the sidestepping or erosion of democratic politics. But there is usually also an implicit claim about disproportion (carried, of course, in the very idea of 'panic') - of getting matters out of hand, of illiberal measures being taken unnecessarily, either to assuage fear or in pursuit of unstated ulterior projects. $^{26}$

The question that hangs in air with respect to such critical charges is how is one to know if securitisation (or panic and the actions that flow from it) is warranted. The common suggestion in studies of both securitisation and moral panics is that it's not. The rhetorical moves are assumed to be inflated and the attendant measures out of proportion. At worst, they construct the very threat to which security actors claim to be responding. As Floyd puts it, critical security studies has a 'widespread normative preference for desecuritization' (p. 23). Its dominant impulse is a rejection of securitisation in favour of ordinary/democratic politics (p. 37), or a will simply to deconstruct and resist forms of power. Similar dispositions have long pervaded the study of moral panics: they are generally taken to be dubious things that sociologists - alert to the 'forces of hyperbole and hysteria'- should expose and call out. ${ }^{27}$ Attention is seldom paid to the morality of whatever panic is being critiqued, and almost never to episodes of 'morally appropriate social reaction'. ${ }^{28}$ The problem is that these critical claims are for the most part not grounded. They are left hanging, something that all urbane, knowing liberals know to be true. Or else they depend upon deflating risk or denying the existence of the 'threat' to which securitisation, or panic, is a response.

Floyd's book is a valuable attempt to move beyond these forms of critique by insinuation, or at least to relocate the hermeneutics of suspicion on firmer soil. Having made a distinction between security as a state of being and security as a set of social and political practices (a distinction to which I return below), she starts from the premise that the latter has no intrinsic value but can be justified if certain conditions are met. In so doing, Floyd moves problems of justification from the margins to the centre of the analysis of securitisation. Her guiding questions are these: how can we decide if any particular act of securitisation is morally justified, or even desirable? Can there be morally permissible, or even virtuous, securitisations? In other words, when is it morally right for a problem to be treated as an urgent priority, lifted out of normal politics, and dealt with by exceptional means?

Using just war theory as her jumping off point, Floyd constructs a 'systematic normative theory' (p. 207) that answers those questions. There is little value in a symposium such as this in (each contributor) supplying a detailed recital of Floyd's just securitisation theory, which by any measure is detailed, clear and rigorous. A brief summary will suffice. For Floyd, just securitisation has to meet three tests: just initiation, just conduct, and just termination. She fleshes out each test with a set of principles, or criteria, for determining what is to count as just in each case.

In respect of initiation, there are five such criteria: there has to be an objective existential threat (which can be intended by an agent, caused by an agent, or agent-lacking, such as flooding or pandemics); a referent object is only morally justified in defending itself if it meets 'basic human needs' such as autonomy and physical health; security actors must possess sincere intentions; the expected benefit from securitisation must exceed the anticipated harm, and the security action must stand a reasonable chance of success. Perhaps the most surprising omission from this

\footnotetext{
${ }^{26}$ Stuart Hall, Chas Critcher, Tony Jefferson, John Clarke, and Brian Roberts, Policing the Crisis (Basingstoke, UK: Macmillan, 1978).

${ }^{27}$ Garland, 'On the concept of moral panic', p. 9.

${ }^{28}$ Ibid., p. 26.
} 
list (especially to someone working in a field in which legitimacy has become central to questions of police and penal power) is that of audience legitimacy. ${ }^{29}$ Crudely put, Floyd thinks that equivalent work is done by the requirement to meet basic human needs (pp. 140-7). The clearest break with extant work on securitisation lies in Floyd's insistence on objective existential threats - an idea, Floyd contends, that critical security studies tends to shun or ridicule (p. 77). The latter hold that security threats are either constructed by and within strategies of securitisation, or else deemed unknowable. Security is, in other words, a label applied to a threat, not inherent in the threat itself. By contrast, Floyd insists on the reality of objective existential threats, which exist regardless of whether they have been framed as such, though she notes that 'real threats' only become matters of security (rather than, say, health or criminal justice) when actors frame and respond to them as such (p. 79). This seems likely to be a bone of ongoing contention - one perhaps where security studies might learn from long-standing debates in sociological criminology on the ontological reality of 'crime'. Is crime a mode of behaviour or a category that 'we' decide to apply to (some, but not other, or all) harmful/threatening acts? ${ }^{30}$ In both cases, my sense is that one can acknowledge the reality/immanence of threats, while continuing to think that the issues at stake concern the analytic and policy lens through which one interprets and responds to such threats.

In respect of the remaining two tests, Floyd delineates a further six principles. Just conduct requires that the security measures used must be appropriate; that these measures must be judged effective and cause the least amount of harm, and that executors must respect a limited amount of human rights. When determining how and when to end a just securitisation, the following criteria apply: desecuritisation must occur as soon as the threat has been neutralised; it must - in rhetoric and action - be declared publicly; and to avoid renewed securitisation, actors should undertake context-specific restorative measures. Unlike the tests with respect to initiation and conduct, which determine what is morally permissible, those referring to just termination specify actions that are morally required. ${ }^{31}$

Rather than taking issue with particular aspects of this framework, or the veracity of any of its specific principles (a task for which others are better equipped), I want to reflect on the animating purposes of just securitisation theory taken as a whole. I take these purposes to be twofold. What Floyd offers first is a theory of limits, one aimed at 'restricting the occurrence and destructiveness of securitization' (p. 9). She acknowledges that securitisation is an inevitable and recurring feature of international relations. She explicitly eschews pacifism and accepts one can imagine securitisations that will pass her tests. This is not at attempt at back-door abolition. Floyd anticipates, however, that the number of securitisations that meet the criteria set by just securitisation theory will be few:

Given that the bar for the moral permissibility of securitization is set high (after all, the goal of JST is to reduce the number of securitizations in the world), it is possible that a real-word example of such a securitization does not exist. (p. 70)

\footnotetext{
${ }^{29}$ Alison Liebling and Justice Tankebe (eds), Legitimacy and Criminal Justice: An International Exploration (Oxford, UK: Oxford University Press, 2013).

${ }^{30}$ Nicola Lacey and Lucia Zedner, 'Criminalization: Historical, legal and criminological perspectives', in Alison Liebling, Shadd Maruna, and Lesley McAra (eds), Oxford Handbook of Criminology ( $5^{\text {th }}$ edn, Oxford, UK: Oxford University Press, 2017).

${ }^{31}$ It seems important to keep in mind here what one might call the cumulative, or even ratcheting, effects of securitisation. David Garland remarks that moral panics 'create effects and leave a legacy' ('On the concept of moral panic', p. 15). The same holds for episodes of securitisation, such that desecuritisation (even on the rare occasions when it is publicly declared) seldom returns social relations and normal politics to the condition they were in prior to securitisation. A common example of this is governments and security professionals finding new uses and targets for powers originally granted for, say, combatting terrorism.
} 
Just securitisation is, secondly, a theory with practical intent. As a backwards-looking theory, it offers scholars tools of moral evaluation that can be deployed to scrutinise and critique securitisations that take place in the world (p. 207). But just securitisation also looks forwards. Floyd's aim is to offer a theory with the 'potential to guide the actions of security practitioners in concrete situations' (p. 4) and render them accountable for their decisions. Indeed, just securitisation theory appears to be couched with this practical purpose in mind. Floyd argues that, as an actionguiding theory, the principles of JST cannot be 'unreasonably demanding' (p. 173). She also suggests that the theory's 'simple and straightforward format (i.e., a list of principles) should mean that it can be easily operationalised, which is to say it has the potential to guide practitioners of security in decision-making' (p. 48).

I want to conclude with some observations on these two ambitions, starting with actionguiding theory. I am sympathetic to the idea that political theory can and should be actionguiding. But proponents of any such guidance need to avoid committing 'the scholastic fallacy' by paying careful sociological attention to its conditions of reception and utilisation. ${ }^{32}$ Two aspects of these conditions are germane in the present case: contestability and time. Securitisation, it seems to me, shares the following feature with moral panic: it is 'almost always an outside observer's category, not a self-description of the participants, at least not while they are participating. ${ }^{33}$ To be sure, securitisation requires speech acts and security activity. But it is also common for security actors to dispute or deny the claim that they are 'securitising' an issue, sometimes while in the process of doing precisely that. This not only makes securitisation distinct from the case of war (notwithstanding war's sometimes fuzzy boundaries), and the just war theorising on which Floyd leans heavily. It also makes it likely that security actors may contest not just the content, but also the applicability, of the tests Floyd proposes that they pass. Cognate considerations apply to questions of time. Like moral panics, securitising episodes are moments of energy, excitement, and anxiety. In such moments, the securitising claim is not only that the response to existential threat has to be lifted from normal political processes. It is also a call to suspend the rules of political time. ${ }^{34}$ It is necessary to do things urgently, with great speed, without delay, as delay is sure to be costly.

I mention these considerations because they speak to the difficulties just securitisation is likely to have in simply getting the hearing it requires in order to stand any hope of guiding action. That hearing may be refused because just securitisation theory starts with the substantive purpose of reducing the number of securitisations in the world (p. 58) and hence threatens to jeopardise 'necessary' protective action. But the theory also extends an invitation to a process of ethical reflection and engagement. By Floyd's own admission some of JST's tests are 'hard to answer and potentially require much work' (p. 134). They demand the gathering and weighing of evidence, and the exercise of comparative judgements about the possible future outcomes of inaction, politicisation, and securitisation (p. 139). All this takes time. It entails a process that is from the outset antithetical to the weight securitisation places on urgent and decisive action.

It is in part for these reasons that, while sympathetic to the aims of just securitisation theory, I remain sceptical about its focus on limits, and minded to conceive of alternative paths that one might take in a bid to reduce the occurrence and destructiveness of securitisation. In a couple of places, Floyd suggests that her project may have 'emancipatory potential' (p. 27). The longdesired goal of emancipation found in some parts of critical security studies 'can', she writes, 'quite conceivably be achieved through just securitization (p. 210). I remain unpersuaded by this claim. What Floyd is offering, it seems to me, is a politics of radical limitation, not a politics

\footnotetext{
${ }^{32}$ Pierre Bourdieu, 'The scholastic point of view', Cultural Anthropology, 5:4 (1990), pp. 380-91.

${ }^{33}$ Garland, 'On the concept of moral panic', p. 20.

${ }^{34}$ Some thoughtful and relevant reflections on the ways in which time intersects with security/securitisation can be found in Martin Holbraad and Morten Axel Pederson (eds), Times of Security: Ethnographies of Fear, Protest and the Future (Abingdon, UK: Routledge, 2013).
} 
of transformation. Her analysis focuses attention on the dynamics of securitising moves and acts. Her concern is to figure out (to return to the distinction between security as a state of being and securitisation as a social and political practice) under what conditions the latter practice might contribute to - rather than erode - the former state of being. This is a liberal project of constraining state power, or seeking principles to ground its use or extension, of setting useable criteria for having less of something deemed necessary but harmful. The supportive references to Lucia Zedner's work on security, and with Andrew Ashworth on principles of preventive justice, underscore the point (p. 46). ${ }^{35}$

But does the justifiability of securitisation, and our resources constraining it, not also depend on the institutions and practices of politicisation, a category that is almost entirely overlooked in this book? My concern here is not with desecuritisation as the supplement of securitisation (p. 178), nor with the question of what happens when securitisation is terminated. Rather, I want to emphasise the properties that 'normal politics' has, or might require, to resist the pull of securitisation in the first place. It is commonly remarked of moral panics that they are surface phenomena, animated by group conflict and status competition, and connected to wider anxieties about transitions in social, economic, and moral order. ${ }^{36}$ This is also arguably true of securitisations. They are not simply the outcome of existential threat and the exceptional measures needed to combat that threat. Their frequency and shape is also conditioned by prevailing status hierarchies and social exclusions (both national and global), and by the capacities of democratic politics to handle or alleviate the resulting tensions. If this is right, it demands attention not only to the moral limits one might place on securitisation. It also calls for a fuller exploration of the forms of democratic politics that conduce to security (as a state of being) and offer constraints on securitisation because of their capacity to govern risk and threat without resort to it. ${ }^{37}$ To make this point is not to detract from Floyd's clear-minded efforts to supply normative grounds to limit securitising agendas. It is simply to highlight the path not taken - one that takes us beyond the liberal project of principles-based constraint and towards an exploration of the kinds of transformative democratic politics that can foster and sustain security in ways that drain the reservoir of social anxiety, and affective support, that securitising actors mobilise and reproduce.

\title{
White supremacy as an existential threat: A response to Rita Floyd's The Morality of Security: A Theory of Just Securitization
}

\author{
Jessica Wolfendale \\ Department of Philosophy, Marquette University, Milwaukee, Wisonsin, United States
}

Rita Floyd's The Morality of Security: A Theory of Just Securitization is an important and insightful book that delineates a theory of just securitisation (modified from the jus ad bellum and jus in bello criteria in just war theory) involving three sets of principles governing the just initiation of

\footnotetext{
${ }^{35}$ Ashworth and Zedner, Preventive Justice; Lucia Zedner, Security (Abingdon, UK: Routledge, 2009).

${ }^{36}$ Garland, 'On the conceptof moral panic', p. 14.

${ }^{37} \mathrm{~A}$ small but telling case in point can be found in Ilum's (Stine Ilum, 'The good city: Counterterrorism and the ethical work of transformation in Copenhagen', Journal of Extreme Anthropology, 4:1 (2020), pp. 157-76) study of how local authorities in Copenhagen mobilised the city's pre-existing 'urban morality' of 'community, openness and inclusiveness' (Ibid., pp. 161, 165) to tame and transform counterterrorist concrete blocks that they felt threatened to securitise public life in the city.
} 
securitisation, just conduct of securitisation, and just desecuritisation. This book is a muchneeded addition to the security studies and just war scholarship.

Here, I explore the potential of Floyd's just securitisation theory (JST) to provide insights into the moral justifiability of non-state groups that are not political entities engaging in resistance against forms of structural violence that pose an existential threat to those groups. Using the case study of the Black Lives Matter (BLM) movement and the threat of white supremacy to African Americans as an illustrative example, I argue that structural forms of violence can meet Floyd's definition of an objective existential threat, justifying the resort to securitisation by groups such as BLM. As Floyd writes in chapter 5:

non-state actors are permitted to [securitize issues normally under the state's jurisdiction], and thus effectively defy the state, when states fail to do their duty to protect against an objective existential threat ... this allows non-state actors to securitize against those unjust regimes that pose objective existential threats to non-state groups within states. ${ }^{38}$

In section 1, I argue that Floyd's analysis of non-state groups leaves open the possibility that loosely organised protest groups such as BLM may constitute a non-state group for the purposes of applying Floyd's just securitisation framework. In section 2, I argue that white supremacy poses an objective existential threat to African Americans, meeting the criterion of just cause in Floyd's JST. The multilayered ways in which white supremacy creates an objective existential threat to African Americans illustrates the potential of Floyd's conception of an objective existential threat to offer insights into the impact of other forms of structural violence, such as entrenched sexism. In section 3, I show that, despite the gains of the civil rights movement, the threat of white supremacy has not been curtailed through legal reform or by democratic means. Thus, groups like BLM may be justified in resorting to extraordinary measures to combat the ongoing threat of white supremacy, including 'whatever most reasonable persons would agree constitutes exceptional means and actions ... non-state securitization can take the form of secession, civil disobedience, acts of sabotage and resistance. ${ }^{39}$ Applying Floyd's JST to the threat of white supremacy thereby demonstrates the value of her approach for thinking about securitisation outside the traditional foci of security studies but, as I discuss in section 3, also reveals some limitations in her theory, particularly in relation to the criterion of reasonable chance of success when applied to non-state groups resisting an unjust state.

\section{Does Black Lives Matter constitute a non-state group?}

Floyd does not explicitly define the kinds of non-state groups that could, in principle, engage in securitisation. On p. 61 she writes that, according to Copenhagen School, 'sufficiently organized societal groupings united by a strong enough "we' identity" ... can revert to a course of conduct that can only be described as securitization'. The Copenhagen School included 'nations, religion and racial groups ${ }^{40}$ in 'societal groupings'. However, in a footnote, Floyd notes that many security scholars now hold that 'other - smaller - non-state securitizing actors than those who can cement a large enough we-feeling are now a possibility', ${ }^{41}$ suggesting that a shared identity is not required in order for a non-state actor to engage in securitisation. But it appears that

\footnotetext{
${ }^{38}$ Floyd, The Morality of Security, pp. 146-7.

${ }^{39}$ Ibid., pp. 61-2. To be clear, I am not advocating for the resort to violence by protest movements against structural oppression. (See the discussion earlier and n. 64 of this article for further clarification of this point). Rather, my intention is to explore the implications of applying Floyd's view to this case study and, by extension, similar protest movements. Using controversial case studies is an important tool in clarifying and extrapolating the normative and political implications of theories of securitisation.

${ }^{40}$ Floyd, The Morality of Security, p. 64, fn. 14.

${ }^{41}$ Ibid., pp. 61-2, fn. 14.
} 
Floyd agrees with the Copenhagen School that non-state groups need to be 'sufficiently organized' to engage in securitisation, although she does not define this term.

In her book, Floyd discusses organised and relatively small groups such as the Sea Shepherd Conservation Society and Arizona Border Recon, ${ }^{42}$ but does not discuss broad protest movements such as BLM. That said, there are two reasons to think that BLM can fit her conception of a nonstate group. Firstly, while some might object that the Black Lives Matter movement does not have legitimate or representative authority to engage in securitisation on behalf of African Americans, Floyd explicitly rejects the criterion of representative authority in her theory of just securitisation, ${ }^{43}$ and so BLM does not need to claim to represent (or be viewed as representing) the interests of all African Americans in order for it to constitute a non-state group for the purposes of applying her framework. ${ }^{44}$ Secondly, while BLM is diverse in its strategies and has a loose organisational structure, it supports and facilitates organised action across the United States and elsewhere to protect the interests of African Americans. As the BLM website states: 'Black Lives Matter Global Network Foundation, Inc. is a global organization in the US, UK, and Canada, whose mission is to eradicate white supremacy and build local power to intervene in violence inflicted on Black communities by the state and vigilantes. ${ }^{45}$ These factors are sufficient, I argue, for BLM to constitute a non-state group for the purposes of evaluating the possibility of just securitisation.

\section{Is white supremacy an existential threat to African Americans?}

In Floyd's theory, just initiation of securitisation by a non-state group requires a just cause: 'an objective existential threat to a referent object, that is to say a danger that - with a sufficiently high probability - threatens the survival or the essential character/properties of either a political or social order, an ecosystem, a non-human species, or individual. ${ }^{246}$ Existential threats include 'all those things that threaten basic human needs, which when met, enable humans to live minimally decent lives'. ${ }^{47}$ Does white supremacy pose an existential threat to African Americans?

The term 'white supremacy' does not simply refer to individuals' racist beliefs. Rather, as Charles Mills explains, white supremacy is a political system, a particular power structure of formal or informal rule, socioeconomic privilege, and norms for the differential distribution of material wealth and opportunities, benefits and burdens, rights and duties' ${ }^{48}$ In a system of white supremacy, whiteness confers social, material, and political advantages on white-identified people at the expense of the welfare and interests of non-white persons: 'From slavery, federal land grants ... through differential access to education, job opportunities, white markets, union membership, and equal wages and promotion chances to ghettoization, restrictive covenants, redlining, white flights, and differential allocation of resources to schools and neighborhoods, whites have historically been materially advantaged over nonwhites, particularly blacks. ${ }^{49}$

The concept of white supremacy thus captures the ways in which interconnected set of practices, norms, and institutions (social, legal, political) privilege white identity and negatively structure the

\footnotetext{
${ }^{42}$ Ibid., pp. 61-2.

${ }^{43}$ Ibid., p. 146.

${ }^{44}$ It is interesting to consider whether African Americans, considered as a group, could constitute a non-state group in Floyd's sense. While I think that it is possible to argue that this could be the case (particularly given that the Copenhagen School allows for religious and ethnic groups to count as non-state groups), Floyd's examples suggest that her conception of non-state groups is restricted to groups that are at least minimally structured and organised. If her account were able to extend to racially based identity groups, then it would raise the interesting possibility that, if the conditions of JST are met, individual African Americans could engage in securitising actions.

${ }^{45}$ Black Lives Matter website: $\{$ https://blacklivesmatter.com/about/\}.

${ }^{46}$ Floyd, The Morality of Security, pp. 19-20.

${ }^{47}$ Ibid., p. 76.

${ }^{48}$ Quoted in Dwayne A. Tunstall, 'Why violence can be viewed as a legitimate means of combating white supremacy for some African Americans', Radical Philosophy Today, 5 (2005), pp. 159-73 (p. 60).

${ }^{49}$ Charles Mills, Blackness Visible: Essays on Philosophy and Race (Ithaca, NY: Cornell University Press, 1998$)$, p. 135.
} 
lives of African Americans (and other people of colour) regardless of the specific intentions of the individuals involved. So defined, white supremacy is embedded within multiple formal and informal institutional and social structures that affect all aspects of life for African Americans, including (but not limited to) the education system, the criminal justice system, and the healthcare system. ${ }^{50}$

But it is one thing to say that white supremacy systematically disadvantages African Americans; it is quite another to claim that it poses an existential threat to African Americans. Below, by applying Floyd's threat categories to the examples of the criminal justice system and the healthcare system I show that white supremacy creates agent-intended threats ('where an aggressor is at the source of the threat intent on harming'), ${ }^{51}$ agent-caused threats (where 'an actor's behaviour leads to a threat to someone else ... without the actor intending to do harm'), ${ }^{52}$ and exacerbates the harm of agent-lacking threats ('threats that occur irrespective of human agency'). ${ }^{53}$ The combined impact of these threats on the ability of African Americans to live minimally decent lives is, I argue, sufficient to meet the definition of an existential threat.

\section{The criminal justice system}

In the American criminal justice system, African Americans are arrested, convicted, sentenced (and sentenced to harsher punishments), ${ }^{54}$ and incarcerated at higher rates than white people who commit similar crimes. ${ }^{55}$ African Americans are also disproportionately the victims of police violence, including lethal violence. ${ }^{56}$ The disproportionate vulnerability of African Americans to police violence, prosecution, arrest, and imprisonment arises from the association of blackness with criminality created by the long-standing unjust securitisation of African American bodies by the state. ${ }^{57}$ This association is so deeply embedded in US society that 'the more stereotypically black a person's physical features are perceived to be, the more that person is perceived as criminal. ${ }^{58}$ The association of blackness with criminality also manifests when white people call the police on African Americans who are engaged in normal, everyday activities such as going for a jog. ${ }^{59}$ This unjust securitisation of African Americans in the domain of everyday life not only undermines African Americans basic sense of safety in their lives by creating an underlying fear that engaging in ordinary daily activities might suddenly attract negative and hostile

${ }^{50}$ Andrew J. Pierce summarises the scope of harm caused by structural discrimination:

the fact that African-Americans have a rate of poverty nearly twice that of whites predisposes them to suffer from other kinds of harm: poorer schools ... greater likelihood of being a victim of violent crime and greater likelihood of imprisonment ... reduced access to commercial services (since banks, grocery stores, and so on prefer to locate in neighborhoods with greater disposable income), and etc. ('Structural racism, institutional agency, and disrespect', Journal of Philosophical Research, 39 (2014), pp. 23-42.

${ }^{51}$ Floyd, The Morality of Security, p. 83.

${ }^{52}$ Ibid., p. 90.

${ }^{53}$ Ibid., p. 86.

${ }^{54}$ Steven Swartzer, 'Race, ideology, and the communicative theory of punishment', Philosophers' Imprint, 19:53 (2019), pp. 1-22 (p. 12).

${ }^{55}$ Ibid., p. 11.

${ }^{56}$ Michael Siegel, 'Racial disparities in fatal police shootings: An empirical analysis informed by critical race theory', Boston University Law Review, 100 (2020), pp. 1069-92. See also Jeffrey A. Fagan and Alexis D. Campbell, 'Race and reasonableness in police killings', Boston University Law Review, 100 (2020), pp. 951-1015.

${ }^{57}$ See Michelle Alexander, The New Jim Crow: Mass Incarceration in the Age of Colorblindness (New York, NY: The New Press, 2012).

${ }^{58}$ Rebecca C. Hetey and Jennifer L. Eberhardt, 'Racial disparities in incarceration increase acceptance of punitive policies', Psychological Science, 25:10 (2014), pp. 1949-54 (p. 1949).

${ }^{59}$ Abigail Hauslohner, Maria Sacchetti, and Shayna Jacobs, 'Incidents of calling police on black people lead states to consider new laws', Washington Post (28 May 2020), available at: $\{$ https://www.inquirer.com/news/nation-world/states-legislation-racist-calls-new-york-new-jersey-oregon-washington-20200528.html\} accessed 15 August 2020. 
attention; it has led to African Americans being murdered by their fellow citizens, as occurred in the killings of Ahmaud Arbery ${ }^{60}$ and Trayvon Martin, ${ }^{61}$ and by the very institution that is supposed to protect them: the police force. The list of unarmed African American men and women who have been killed by police continues to grow, despite decades of protest. ${ }^{62}$ This shows that the threat of violence from police and fellow citizens is not limited to African Americans who engage in criminal activities but infiltrates the daily lives of all Africans Americans.

Applying Floyd's threat categories to the threat posed by the criminal justice system to African Americans leads to the following analysis. Firstly, police officers who engage in disproportionate and excessive use of force (including lethal force) against African Americans pose an agent-intended threat because such officers, by choosing to fire their weapons or otherwise physically attack an African American person, directly intend to harm. In contrast, the threat posed by prosecutors, judges, and other actors within the criminal justice system whose actions reinforce the disproportionate vulnerability of African Americans to arrest, prosecution, and severe punishment may be more accurately described as agent-caused, since while these individuals' actions are intentional, it need not be the case that they are directly intended to cause harm. However, in both cases the threat posed by the criminal justice system is severe: African Americans are disproportionately vulnerable to the unjust deprivation of liberty via prosecution, arrest, and severe sentencing and to the direct threat of physical violence (including lethal violence) at the hands of police and even the general public.

\section{The healthcare system}

In the US healthcare system, there is compelling evidence that white supremacy contributes to worse disease and mortality rates for African Americans compared to white Americans. ${ }^{63}$ For example, 'Black, American Indian, and Alaska Native (AI/AN) women are two to three times more likely to die from pregnancy-related causes than white women. ${ }^{64}$ The stark disparity in health outcomes between African American and white Americans became startlingly clear during the COVID-19 pandemic, which has disproportionately affected African Americans and other minority communities. ${ }^{65}$

The causes of this neglect of and lack of care for the health of African Americans are complex and intersect with the impact of racial discrimination in housing, education, and access to

\footnotetext{
${ }^{60}$ Sean Collins, 'The killing of Ahmaud Arbery, an unarmed black jogger in Georgia, explained', Vox (24 June 2020), available at: \{https://www.vox.com/identities/2020/5/6/21249202/ahmaud-arbery-jogger-killed-in-georgia-video-shooting-grandjury\} accessed 20 August 2020.

${ }^{61}$ Ta-Nehesi Coates, 'Trayvon Martin and the irony of American justice', The Atlantic (15 July 2013), available at: \{https:/ www.theatlantic.com/national/archive/2013/07/trayvon-martin-and-the-irony-of-american-justice/277782/\} accessed on 21 August 2020.

${ }^{62}$ See Siegel, 'Racial disparities', and Michael Marshall, 'US police kill up to 6 times more black people than white people', New Scientist (24 June 2020), available at: \{https://www.newscientist.com/article/2246987-us-police-kill-up-to-6-times-moreblack-people-than-white-people/\#ixzz6W8s5Nwd1\} accessed on 24 August 2020; and John Swaine and Ciara McCarthy, 'Young black men again faced highest rate of U.S. police killings in 2016', The Guardian (8 January 2017), available at: \{https://www.theguardian.com/us-news/2017/jan/08/the-counted-police-killings-2016-young-black-men\} accessed on 2 September 2020.

${ }^{63}$ See, for example, Gilbert C. Gee and Chandra L. Ford, 'Structural racism and health inequities: Old issues, new directions', Du Bois Review, 8:1 (2011), pp. 115-32, and David R. Williams and Ronald Wyatt, 'Racial bias in health care and health: Challenges and opportunities', JAMA, 314:6 (2015), pp. 555-6.

${ }^{64}$ Center for Disease Control and Prevention, 'Racial and Ethnic Disparities Continue in Pregnancy-Related Deaths' (16 September 2019), available at: \{https:/www.cdc.gov/media/releases/2019/p0905-racial-ethnic-disparities-pregnancy-deaths. html\} accessed 17 March 2021.

${ }^{65}$ Christian Weller, 'Systemic racism makes Covid-19 much more deadly for African-Americans', Forbes (18 June 2020), available at: $\{$ https://www.forbes.com/sites/christianweller/2020/06/18/systemic-racism-makes-covid-19-much-more-deadlyfor-african-americans/\#10bc476b7feb\} accessed 28 August 2020.
} 
transport, among other factors. ${ }^{66}$ In some cases, this neglect might be the result of direct racial bias on the part of healthcare practitioners (which would be an instance of an agent-intended threat), but in other cases such neglect may not be intentional, and would therefore be more accurately described as an agent-caused threat. However, even in cases where this neglect is not the result of direct bias, it is clearly culpable: given the well-documented history of racial bias in the healthcare system, no one involved 'can reasonably claim obliviousness ${ }^{67}$ about the existence and impact of racial bias (conscious or unconscious) on African Americans' health outcomes. Additionally, as is clear from the disproportionate impact of the COVID pandemic on African Americans and other minorities, white supremacy within the healthcare system exacerbates the harmful impacts of agent-lacking threats, such as disease. The upshot is that the threat posed by white supremacy in the healthcare system to the basic needs and interests of African Americans manifests in multiple ways that seriously harm African Americans' basic physical wellbeing.

I do not have space here to discuss the many other contexts in which white supremacy poses a threat to the needs and welfare of African Americans, such as via housing discrimination, educational discrimination, and residential segregation. But, just considering how white supremacy manifests in the criminal justice and healthcare systems is sufficient, I argue, to show that white supremacy meets the definition of an objective existential threat to African Americans. It threatens their ability to live free from the fear of arbitrary arrest and the threat of violence, and their ability to be physically secure and have access to basic healthcare. Thus, it threatens their 'basic human needs, which when met, enable humans to live minimally decent lives ${ }^{68}$ and causes them 'to be fundamentally disabled in the pursuit of one's vision of the good' ${ }^{69}$ In the words of Tommy Curry, 'White racism, black poverty, and the systematic incarceration of African descended people in America have rendered the ability of blacks to determine their own economic, social and cultural development virtually impossible. ${ }^{, 70}$

The examples discussed above show that white supremacy is embedded in and reinforced by US state institutions (such as the criminal justice system) and illustrate how the threat of white supremacy in these institutions is exacerbated by the state's failure to adequately address racial disparities in healthcare and other contexts. Thus, the state has not only failed to protect African Americans from the threat of white supremacy; state institutions themselves are part of the threat. This provides the just cause for the just securitisation of white supremacy by African Americans: 'when states fail to do their duty to protect against an objective existential threat ... this allows non-state actors to securitize against those unjust regimes that pose objective existential threats to non-state groups within states. ${ }^{, 71}$

\section{Securitising white supremacy}

The securitisation of white supremacy meets the criterion of just cause in Floyd's JST: there exists an existential threat to a just referent object. However, for the securitisation of white supremacy to be just, the following criteria must also be satisfied: right intention ('the right intention of securitization is the just cause'), proportionality ('the expected good gained from securitization must be greater than the expected harm from securitization'), and reasonable chance of success ('the chances of achieving the just cause must be judged greater than those of alternatives to securitization').

\footnotetext{
${ }^{66}$ Center for Disease Control and Prevention, 'African American Health' (3 July 2017), available at: \{https://www.cdc.gov/ vitalsigns/aahealth/index.html\} accessed 17 March 2021.

${ }^{67}$ Floyd, The Morality of Security, p. 91.

${ }^{68}$ Ibid., p. 76.

${ }^{69}$ Ibid., p. 105.

${ }^{70}$ Tommy J. Curry, 'Please don't make me touch 'em: Towards a critical race Fanonianism as a possible justification for violence against whiteness', Radical Philosophy Today, 5 (2007), pp. 133-58 (p. 134).

${ }^{71}$ Floyd, The Morality of Security, pp. 146-7.
} 
Securitisation must also be conducted justly; security measures must be 'appropriate and should aim only to address the objective existential threat ... must be judged effective ... [and] must respect a limited number of relevant human rights in the execution of securitization'. ${ }^{72}$

What would the securitisation of white supremacy involve? According to Floyd, securitisation by non-state actors involves 'whatever most reasonable persons would agree constitutes exceptional means and actions ... non-state securitization can take the form of secession, civil disobedience, acts of sabotage and resistance. ${ }^{73}$ Later she elaborates, 'what most reasonable persons would agree constitutes exceptional means and actions, most notably perhaps, in terms of the amount of harm, risked/caused or intended, and/or the level of violence employed'. ${ }^{74}$ So, to ask whether BLM can securitise the threat of white supremacy is to ask whether BLM may engage in or promote acts of civil disobedience, sabotage, and even acts of violence to mitigate the threat of white supremacy. Could such securitisation meet the other criteria of Floyd's JST?

\section{Proportionality and reasonable chance of success ${ }^{75}$}

In her discussion of proportionality, Floyd focuses on the potential harms resulting from state securitisations, ${ }^{76}$ and so there is little to guide us when applying this criterion to non-state securitisations. However, it is prima facie plausible to think that non-state securitisations will typically cause less overall harm than state securitisations simply because non-state groups lack the resources that states possess. When a state securitises a threat, it has the power to restrict the rights and freedoms of millions of people and to unleash police and military power on an enormous scale, all of which must be weighed against the potential good to be achieved by securitisation. In contrast, the securitising actions available to a non-state group defending against an existential threat include civil disobedience, sabotage, and even acts of violence against property and persons, if such violence 'serves some defensive purpose'. ${ }^{77}$ While the harm caused by these actions may be severe, when compared to the scale of the existential threat being defended against, it is at least probable that the proportionality requirement will be more easily met than with state securitisations. ${ }^{78}$

Turning to the criterion of reasonable chance of success (which is also a criterion of just conduct of securitisation), ${ }^{79}$ Floyd states that 'securitization's prospect for succeeding in securing the referent object must be established comparatively against the alternatives to securitizing. ${ }^{80}$ Could

\footnotetext{
${ }^{72}$ All quotes from Floyd, The Morality of Security, p. 20. The idea that securitisation (defined as a state of exception to normal laws and procedures) should still require the protection of some rights might seem strange. But this view is consistent with the just war framework from which Floyd draws her inspiration. Even in a state of war, the laws of war still require the protection of certain basic rights. For example, directly targeting civilians is illegal, as is the use of tactics such as torture. Few, if any, contemporary scholars on just war theory argue that a state of war involves the suspension of all moral rights. I thank an anonymous reviewer for encouraging me to clarify this point.

${ }^{73}$ Floyd, The Morality of Security, pp. 61-2.

${ }^{74}$ Ibid., p. 139.

${ }^{75}$ I won't say much about right intention here, but there's no reason to think that the securitisation of white supremacy could not be conducted with just cause as the aim.

${ }^{76}$ Floyd, The Morality of Security, pp. 128-35.

${ }^{77}$ Ibid., p. 166. As Floyd elaborates, 'killing someone who negligently fails to prevent a threat can only be permissible if killing them is causally effective in preventing that threat.' So, to reiterate my earlier point in fn. 26 , noting that the use of violence is one of the securitising actions available to a non-state group is not to say that such acts of violence are therefore justified.

${ }^{78}$ This is consistent with recognising that the actions of non-state groups, such as the $9 / 11$ attacks, can cause extreme devastation. But even in the case of 9/11, the response of the US to these attacks has resulted in a war that has lasted more than twenty years and resulted in the deaths of thousands of military personnel, and hundreds of thousands of civilians. This illustrates my point that state securitisations are likely to inflict far more harm than non-state securitisations. I thank an anonymous reviewer for raising this question.

${ }^{79}$ 'The security measures must be judged effective in dealing with the threat.' Floyd, The Morality of Security, p. 20.

${ }^{80}$ Ibid., p. 138.
} 
the threat of white supremacy be addressed through alternatives to securitisation ('commonly accepted political means not generally considered harmful'), ${ }^{81}$ such as democratic processes, legal challenges to racist laws, and appeals to the legislature?

Unfortunately, we have good reason to doubt the effectiveness of these methods in mitigating the threat of white supremacy. Historically, the most egregious institutionalised forms of white supremacy - slavery and segregation - were ended not by 'political means not generally considered harmful', but only after decades of conflict, civil disobedience, sabotage, and violent protest. For example, while the civil rights movement led to remarkable political and legal gains for African Americans, these gains were not achieved through regular political and democratic processes but through a range of securitising tactics including civil disobedience, protest, and the use of violence. The civil rights movement is often depicted as non-violent movement, but there was, in fact, significant disagreement among the groups involved in the movement regarding the use of violence: 'The modern civil rights movement was a social movement for basic citizenship and human rights employing many tactics, and although perhaps non-violent direct action was more common, armed selfdefense and other forms of armed resistance were employed as well. ${ }^{82}$ That these tactics led to the passage of the 1964 Civil Rights Act provides reason to think that the conversion of these discriminatory laws was caused, in part, by violence and subversion' ${ }^{83}$

The apparent success of the tactics used by the civil rights movement in leading to significant legal changes suggests that the use of similar securitising tactics by BLM may be justified under Floyd's framework. But this is too quick. To evaluate whether the use of securitisation tactics by BLM meets the reasonable chance of success criterion, we need to clarify what constitutes 'success'.

For example, while the legal gains of the civil rights movement were remarkable, these gains have not led to the mitigation of the ongoing threat of white supremacy and, in some cases, have been substantially reversed. For example, one of the most important pieces of civil rights legislation the 1965 Voting Rights Act - has been progressively undermined by the Supreme Court and state legislative decisions that have led to a rise in voter suppression tactics (such as redistricting, voter ID laws, and felon disenfranchisement) that disproportionately affect African Americans and other minority groups. ${ }^{84}$ Similarly, attempts to use the court system to change criminal laws that cause disparate harm to African Americans, such as drug sentencing laws, have failed. ${ }^{85}$ As Paul Butler points out, 'historically, legislators and judges have remedied racist law, but they have also, on other occasions, established and reinforced it. ${ }^{, 86}$ Finally, even if the legal protections afforded by the Civil Rights Act and the Voting Rights Act were not being undermined, white supremacy also threatens African Americans' basic needs through social practices and attitudes that are entrenched within state institutions and cannot be easily addressed through legal changes. For example, attempts to change racist attitudes in policing through implicit bias training and the use of body cameras has had no impact on the disproportionate use of police violence against African Americans. ${ }^{87}$ Indeed, the problem has

\footnotetext{
${ }^{81}$ Ibid., p. 139.

${ }^{82}$ Akinyele O. Umoja, 'The ballot or the bullet: A comparative analysis of armed resistance in the civil rights movement', Journal of Black Studies, 29:4 (1999), pp. 558-78.

${ }^{83}$ Paul Butler, 'By any means necessary: Using violence and subversion to change unjust laws', UCLA Law Review, 50:2 (2002), p. 726.

${ }^{84}$ See, for example, Gilda R. Daniels, Uncounted: The Crisis of Voter Suppression in American (New York, NY: New York University Press, 2020); Atiba R. Ellis, 'Race, class, and structural discrimination: On vulnerability within the political process', Journal of Civil Rights and Economic Development, 28:1 (2015), pp. 33-60; and P. R. Lockhart, 'How Shelby County v. Holder upended voting rights in America', Vox (25 June 2019), available at: \{https://www.vox.com/policy-and-politics/ 2019/6/25/18701277/shelby-county-v-holder-anniversary-voting-rights-suppression-congress\} accessed 19 March 2021.

${ }^{85}$ Butler, 'By any means necessary', pp. 728-37.

${ }^{86}$ Ibid., p. 725.

${ }^{87}$ Sam Levin, “It's not about bad apples": How US police reforms have failed to stop brutality and violence', The Guardian (16 June 2020), available at: \{https://www.theguardian.com/us-news/2020/jun/16/its-not-about-bad-apples-how-us-policereforms-have-failed-to-stop-brutality-and-violence\} accessed 24 August 2020.
} 
worsened: a recent report found that '[w]hite supremacist groups have infiltrated US law enforcement agencies in every region of the country over the last two decades. ${ }^{88}$

The failure of political, legal, and reform approaches to mitigating the ongoing threat of white supremacy suggests that while the securitisation tactics of the civil rights movement may have been successful in the short term, they were not successful if 'success' refers to the mitigation of the ongoing threat of white supremacy. Michelle Alexander, for example, argues that the explicit racism in the Constitution and Jim Crow laws prior to the passage of the 13th Amendment and the Civil Rights Act has morphed into less explicit forms of discrimination (for example, through the disproportionate incarceration of African Americans). ${ }^{89}$ What does this mean for the case of BLM? The reasonable chance of success criterion is applied prior to securitisation and thus is based on a 'best guess' as to whether securitisation will mitigate the existential threat. This raises two questions. Firstly, is the use of securitisation tactics by BLM likely to succeed in mitigating the threat posed by white supremacy? Secondly, if the answer to the first question is 'no', does this mean that we should accept that non-state groups opposing unjust states will be unlikely to meet the criteria of just securitisation, or should we reconsider whether the criterion ought to be applied to such groups?

\section{Would securitisation by BLM be likely to succeed?}

Given the ultimate failure of the civil rights movement to mitigate the threat of white supremacy, it is reasonable to assume that the securitisation tactics available to non-state protest groups like BLM who are opposing unjust state oppression will be unsuccessful, particularly given the likelihood of violent state backlash. The difficultly of meeting the 'reasonable chance of success' criterion puts BLM and similarly situated groups in an impossible situation: fight white supremacy (or other forms of severe oppression and injustice) through 'ordinary political means' (which are almost certain to fail, as we have seen) or do nothing. So, although Floyd writes that, 'non-state actors are permitted to ... effectively deny the state, when states fail to protect against an objective existential threat', ${ }^{90}$ insisting on a reasonable chance of success criterion makes denying the state next to impossible for non-state protest groups with few resources who are fighting forms of oppression embedded in state institutions and practices.

This brings us to the second question: should we accept that non-state groups may rarely, if ever, meet the criteria of just securitisation and thus should not engage in securitisation, or should we reconsider the reasonable chance of success criterion as applied to non-state groups facing an existential threat posed by state systems of oppression?

\section{The moral value of futile resistance}

I want to end my discussion of the case of BLM by proposing that the criterion of reasonable chance of success should be modified, if not removed entirely, when JST is applied to cases of non-state groups opposing state oppression. I suggest that in cases where non-state groups meet the other criteria of Floyd's JST (such as just cause), there can be a moral justification for engaging in securitisation that is likely to be futile. For example, during the eighteenth and nineteenth centuries there were several armed slave uprisings, all of which failed ${ }^{91}$ and none of which had a reasonable chance of success under any plausible definition of 'reasonable'. Under Floyd's JST, these uprisings were unjustified. Yet, today they are regarded as heroic acts

\footnotetext{
${ }^{88}$ Sam Levin, 'White supremacists and militias have infiltrated police across US, report says', The Guardian (27 August 2020), available at: \{https://www.theguardian.com/us-news/2020/aug/27/white-supremacists-militias-infiltrate-us-policereport\} accessed 22 August 2020.

${ }^{89}$ Alexander, The New Jim Crow.

${ }^{90}$ Floyd, The Morality of Security, pp. 146-7.

${ }^{91}$ Butler, 'By any means necessary', p. 749.
} 
of resistance. This suggests that securitisation by non-state groups facing existential threats caused by unjust states can have significant moral value even if such securitisation is unlikely to successfully mitigate the existential threat. This does not mean that non-states groups are obliged to engage in futile resistance. Rather, it means that such groups may be morally justified in doing so, if they choose to take that path. For example, engaging in securitising actions can be a way of asserting the moral value of human dignity and freedom in the face of oppression. As Derrick Bell argues, 'the struggle for freedom is at the bottom, a manifestation of our humanity which survives and grows stronger through resistance to oppression. ${ }^{\text {,92 }}$

Perhaps this concern could be addressed by broadening the concept of 'success' in the reasonable chance of success criterion to include the achievement of moral goods such as the assertion of human dignity. I think, however, that this is an unworkable solution as it is hard to know how one would measure chance of success in relation to such aims. Instead, I propose that Floyd consider qualifying her reasonable chance of success criterion, or even removing it entirely, and allowing for the possibility of just (but likely futile) securitisations on the part of non-state groups facing unjust state regimes who meet the other criteria of her JST. ${ }^{93}$ Give that Floyd's criteria of just conduct of securitisation sets limits on the kinds of securitising actions that may be used by a securitising actor, ${ }^{94}$ this proposal would mean that there would be significant moral constraints on the cases that would meet the criteria of her JST.

\section{Conclusion}

Applying Floyd's theory of just securitisation to the case of BLM and the threat of white supremacy illustrates the value of her approach in recognising that non-state protest groups facing existential threats from unjust and oppressive states may engage in securitisation. Her definition of an existential threat allows a broader understanding of how a group's basic needs may be threatened in different ways. However, the difficulty that BLM and similarly situated groups would have in meeting the reasonable chance of success criterion suggests a need to revise that criterion to accommodate the possibility, and capture the moral significance, of just but futile resistance. Otherwise, her theory would make it virtually impossible for non-state groups to engage in securitisation against powerful unjust states. ${ }^{95}$

\footnotetext{
${ }^{92}$ Derrick Bell, 'The racism is permanent thesis: Courageous revelation or unconscious denial of racial genocide', Capital University Law Review, 22 (1992), pp. 571-87 (p. 573).

${ }^{93}$ I think a case can be made for differentiating state and non-state securitisations here. For example, futile securitisations by a state would, I argue, be far less justifiable given the immense harm that states can inflict via acts of securitisation. Additionally, my proposal would problematise the proportionality criterion in both the initiation and conduct of securitisation. If securitisation by a non-state group could be justified as an affirmation of human dignity with little chance of success (assuming such a group has just cause and meets the other criteria) the harm caused by such securitisation would be disproportionate because it would not be counterbalanced by the good of mitigating the existential threat. One way of addressing this issue would be to incorporate the good of affirming dignity into the proportionality calculation - a suggestion I cannot explore in detail here.

${ }^{94}$ Floyd, The Morality of Security, pp. 153-60. For example, when considering the use of armed resistance by BLM and similarly situated groups, such violence would only be justified if 'it serves some defensive purpose. Killing someone who negligently fails to prevent a threat can only be permissible if killing them is causally effective in preventing that threat.' Floyd, The Morality of Security, p. 166.

${ }^{95}$ Floyd, The Morality of Security, p. 189. Applying her theory to the case of white supremacy also raises questions about the desecuritisation of white supremacy. For example, does the state bear 'remedial responsibility' for the harms of white supremacy? What restorative acts would redress these harms? These questions further illustrate the potential of her theory to expand our thinking about securitisation beyond the traditional state-centred focus of security studies.
} 


\title{
Just securitisation and transnational counterterrorism
}

\author{
Fiona de Londras
}

Professor of Global Legal Studies, Birmingham Law School, University of Birmingham, and Honorary Professor, College of Law, the Australian National University

Everyone who reads a book does so from the comfort of their own 'disciplinary home'. They also do so in a particular moment in time. Both of these factors colour their reading of the book, and shape their reactions to it. This is as much the case for my reading of Rita Floyd's The Morality of Security as it is for anyone else. Cross-disciplinary reading also lends itself to re-translations, mistranslations, and illegibility, but in those moments of muddled and re-made meaning new insights, questions and ideas can emerge. My remarks here are offered in the hope of catalysing the curiosities that such cross-disciplinary reading can nurture, as indeed my reading of this compelling and provocative book has awoken in me.

My disciplinary home is law. I am particularly interested in the content, nature, working and dilemmas of law as they relate to rights, security, and transnationalism. I read this book as I was finishing one of my own, on transnational counterterrorism and the risks that it poses to constitutionalism, accountability, and ultimately the 'international community' (whatever that might be). This, then, is the register in which I read Floyd, and related her insights to my own work on transnational counterterrorism ${ }^{96}$ and the remarkable, deep, impactful, and interminable securitisation of terrorism that has taken hold across international, regional, and national scales in the last twenty years.

While others will be able to speak about the rich contribution of The Morality of Security to just war theory, the Copenhagen School, or politicisation, I will try to put some of Floyd's insights into conversation with transnational counterterrorism. Elsewhere, I have defined transnational counterterrorism as an 'assemblage of laws, institutions, forums, processes, bureaucracies, and cooperative networks ${ }^{97}$ that emerge from and operate on transnational scales, and I adopt that definition here when I refer to transnational counterterrorism. In my view, transnational counterterrorism poses some real challenges to, and offers rich potential for expanding, the account of just securitisation and desecuritisation that Floyd lays out here. This is not least because the transnationalisation of securitisation in the wake of the 9/11 attacks has resulted in the proliferation of forums, pluralisation of actors, mushrooming of institutions, embedding of practices, and promulgation of laws on multiple and overlapping scales to such an extent that it calls into question an insistence on exceptionality as core to securitisation and instead, I think, compels us to think about what it means for securitisation and its products to become embedded and concretised, but in such a way that politicisation is stymied if not made impossible.

Prior to the attacks of $9 / 11$ the transnational legal order had given some, but not very intensive, attention to terrorism. There were individual terrorism-related conventions that related to specific forms or acts of terrorism like hijacking or the suppression of terrorist financing. ${ }^{98}$

\footnotetext{
${ }^{96}$ Fiona de Londras and Jasmin Tregidga, 'Rights, proportionality, and process in EU counter-terrorism law-making', International Journal of Constitutional Rights (2021); Fiona de Londras, 'Transnational counter-terrorism: A problématique', Current Legal Problems, 72 (2019), pp. 203-51; Fiona de Londras, 'Politicisation, law and rights in the transnational counter-terrorism space: Indications from the regulation of foreign terrorist fighters', European Review of International Studies, 5:3 (2018), pp. 115-38; Fiona de Londras, 'Accounting for rights in EU counter-terrorism: Towards effective review', Columbia Journal of European Law, 22:2 (2016), pp. 237-74; Fiona de Londras and Josephine Doody (eds), The Impact, Legitimacy and Effectiveness of EU Counter-Terrorism (London, UK: Routledge, 2015). Fiona de Londras, The Practice and Problems of Transnational Counter-Terrorism (Cambridge, UK: Cambridge University Press, 2022).

${ }^{97}$ de Londras, 'Transnational counter-terrorism'.

${ }^{98}$ Conventions deposited with the Secretary-General of the UN: Convention on the Prevention and Punishment of Crimes against Internationally Protected Persons, including Diplomatic Agents, adopted by the General Assembly of the United
} 
There was a terrorism-related sanctions process established under the Security Council, but its reach was reasonably contained. ${ }^{99}$ And of course there was a long running attempt to define terrorism in a legally binding way, ${ }^{100}$ an attempt that continues and remains incomplete. However, there was no transnational counterterrorism law per se, ${ }^{101}$ there was no institutional infrastructure dedicated to countering terrorism at the international level (although some forms of transnational policing cooperation did engage with terrorism in the course of their work), and there was not yet the kind of total embedding of counterterrorism in transnational capital (especially the financial and telecommunications sectors) that would we are now accustomed to. All of that changed in September 2001.

That of course is not to suggest that terrorism (or counterterrorism) started with the 9/11 attacks, ${ }^{102}$ but it is to suggest - I think rightly - that terrorism was subjected to a massive, generalised, and enduring transnational securitisation in the wake of those attacks, at least inasmuch as those of us approaching it from a legal disciplinary perspective might see it. However, it seems to me that transnational counterterrorism troubles some of the ways in which securitisation is constructed both by Floyd and by the many scholars to whom she outlines an intellectual debt in chapter 2 and, in particular, the insistence on 'exceptional' measures as part of it.

Let us start, like Floyd (p. 49) does, with the Copenhagen School's notion that securitisation comprises (1) a securitising move, (2) an audience acceptance of the securitising move, and (3) the use of extraordinary measures to deal with it.

Shifting our gaze to the transnational scale we can see very clearly a securitising move. Here I look not at Security Council Resolution 1368 (2001), which seemed to endorse military responses to terrorism and some have argued gave states a 'blank check' to respond to terrorist engagement with military force. ${ }^{103}$ There is an understandable temptation to zone in on this Resolution and resulting militarisation when one considers securitisation of terrorism at UN level following 9/11.

Nations on 14 December 1973; International Convention against the Taking of Hostages, adopted by the General Assembly of the United Nations on 17 December 1979; International Convention for the Suppression of Terrorist Bombings, adopted by the General Assembly of the United Nations on 15 December 1997; International Convention for the Suppression of the Financing of Terrorism, adopted by the General Assembly of the United Nations on 9 December 1999. Conventions deposited with other depositaries: Convention on Offences and Certain Other Acts Committed on Board Aircraft, signed at Tokyo on 14 September 1963 (Deposited with the Secretary-General of the International Civil Aviation Organization); Convention for the Suppression of Unlawful Seizure of Aircraft, signed at The Hague on 16 December 1970 (Deposited with the Governments of the Russian Federation, the United Kingdom and the United States of America); Convention for the Suppression of Unlawful Acts against the Safety of Civil Aviation, signed at Montreal on 23 September 1971 (Deposited with the Governments of the Russian Federation, the United Kingdom and the United States of America); Convention on the Physical Protection of Nuclear Material, signed at Vienna on 3 March 1980 (Deposited with the Director- General of the International Atomic Energy Agency); Protocol on the Suppression of Unlawful Acts of Violence at Airports Serving International Civil Aviation, supplementary to the Convention for the Suppression of Unlawful Acts against the Safety of Civil Aviation, signed at Montreal on 24 February 1988 (Deposited with the Governments of the Russian Federation, the United Kingdom and the United States of America and with the Secretary-General of the International Civil Aviation Organization); Convention for the Suppression of Unlawful Acts against the Safety of Maritime Navigation, done at Rome on 10 March 1988 (Deposited with the Secretary-General of the International Maritime Organization); Protocol for the Suppression of Unlawful Acts against the Safety of Fixed Platforms Located on the Continental Shelf, done at Rome on 10 March 1988 (Deposited with the Secretary-General of the International Maritime Organization); Convention on the Marking of Plastic Explosives for the Purpose of Detection, signed at Montreal on 1 March 1991 (Deposited with the Secretary-General of the International Civil Aviation Organization).

${ }^{99}$ Security Council Resolution 1267 (1999).

${ }^{100}$ See, for example, Eva Herschinger, 'A battlefield of meanings: The struggle for identity in the UN debates on a definition of international terrorism', Terrorism and Political Violence, 25:3 (2013), p. 183.

${ }^{101}$ It may be argued that there was some transnational criminal law that applied to terroristic activity. See Neil Boister, An Introduction to Transnational Criminal Law ( $2^{\text {nd }}$ edn, Oxford, UK: Oxford University Press, 2018), ch. 7.

${ }^{102}$ Stuart Elden, Terror and Territory: The Spatial Extent of Sovereignty (Minneapolis, MN: University of Minnesota Press, 2009), p. xii.

${ }^{103}$ Chantal de Jonge Oudraat, 'The role of the Security Council', in Jane Boulden and Thomas Weiss (eds), Terrorism and the UN: Before and After September 11 (Bloomington, IN: Indiana University Press, 2004). 
However, I suggest that we look instead at Security Council Resolution 1373 (2001). This was initiated by the United States and adopted, unanimously, only 17 days after the attacks of 11 September 2001. In it the Security Council took the unprecedented step $^{104}$ of using its Chapter VII powers to oblige all member states of the United Nations to adjust their domestic criminal law to disrupt and criminalise terrorist financing, as well as establishing the Counter-Terrorism Committee, ${ }^{105}$ expanding significantly the sanctions regime, ${ }^{106}$ and harnessing the international duty of interstate cooperation decisively to transnationalise counterterrorism. As Isabel Roele puts it, the Security Council articulated a 'no weak links' approach to counterterrorism ${ }^{107}$ by focusing on attempting to harmonise a minimum content of domestic law which, in turn, empowers policing, security, and intelligence activity and, through the sanctions regime, necessarily folds financial institutions (and soft international institutional that regulate them, like the Financial Action Task Force $)^{108}$ into the transnational counterterrorism milieu.

Audience acceptance was both voluntary (for example, more or less every member state reported its progress towards implementation to the Counter-Terrorism Committee within a few months - an almost unprecedented level of compliance with a reporting obligation), and coerced. By using Chapter VII of the Charter of the United Nations (by which the Security Council can bind member states to prescribed action), the Security Council made Resolution 1373 (2001) and its content binding on all member states, and by setting up an institutional infrastructure to 'monitor' and 'support' it, it created the apparatus for an 'infra-law' ${ }^{\text {'09 }}$ of enforcement unlike anything we had seen in the counterterrorism space before.

However, the question that niggles at me is whether the measures introduced to deal with terrorism were 'extraordinary' or 'exceptional'. They were certainly extraordinary when seen against the antecedent approach, which was to allow states to accede (or not) to international conventions at their own pace (and in fact ratification was very low and very slow before September 2001) and largely to leave terrorism as a 'phenomenon' for states to deal with. With Resolution 1373 (2001) terrorism was recast as a matter of international peace and security and thus the Security Council was placed right at the heart of it. While Floyd, like many others, focuses on the 'Global War on Terror' and militarisation, from a long-term, normative, and institutional perspective it is these moves of norm setting, institution building, and expectation shifting that were the most significant and transformative parts of the transnational reaction to $9 / 11 .^{110}$ They have continued unabated since with states now obliged, among other things, to criminalise incitement to terrorism, ${ }^{111}$ to require airlines to collect $\mathrm{API}^{112}$ and $\mathrm{PNR},{ }^{113}$ to establish biometric databases, ${ }^{114}$ and more. The Counter-Terrorism Committee now has its own support structure (the CounterTerrorism Executive Directorate), ${ }^{115}$ and there is also a UN Office for Counter-Terrorism ${ }^{116}$ (with satellite offices in countries around the world), a Counter-Terrorism Centre (funded largely

\footnotetext{
${ }^{104}$ Paul C. Szasz, 'The Security Council starts legislating', American Journal of International Law, 96:4 (2002), p. 901.

${ }^{105}$ Security Council Resolution 1373 (2001), operative para. 6.

${ }^{106}$ See generally the excellent exposition of the growth, reach, and technologies of contemporary counterterrorism sanctions regimes offered by Gavin Sullivan, The Law of the List: UN Counterterrorism Sanctions and the Politics of Global Security Law (Cambridge, UK: Cambridge University Press, 2020).

${ }^{107}$ Isobel Roele, 'Sidelining subsidiarity: United Nations Security Council "legislation" and its infra-law', Law and Contemporary Problems, 79:2 (2016), pp. 189-214.

${ }^{108}$ See generally Ben Hayes, Counter-Terrorism, 'Policy Laundering', and the FATF: Legalising Surveillance, Regulating Civil Society (TNI/Statewatch, 2012).

${ }^{109}$ Roele, 'Sidelining subsidiarity'.

${ }^{110} \mathrm{de}$ Londras, 'Transnational counter-terrorism'.

${ }^{111}$ Security Council Resolution 1624 (2005).

${ }^{112}$ Security Council Resolution 2178 (2014).

${ }^{113}$ Security Council Resolution 2396 (2017).

${ }^{114}$ Security Council Resolution 2322 (2016).

${ }^{115}$ Security Council Resolution 1535 (2004).

${ }^{116}$ General Assembly Resolution 71/291 (2017).
} 
by Saudi Arabia), a huge project of capacity building at national and regional level, and an everexpanding project of 'countering violent extremism conductive to terrorism' ${ }^{117}$ All of this can be directly linked back to Resolution 1373 (2001) and to the securitising moves of the United States and United Kingdom, in particular, at that time, since joined by other securitising actors including especially France, Egypt, and Saudi Arabia all of whom have taken leading roles in sponsoring Security Council Resolutions, developing frameworks and standards, and funding the UN counterterrorism infrastructure.

Given all of this, it is really not clear to me that the measures introduced in and since 2001 should be said to have been 'extraordinary' because they lack (and were intended to lack) temporal restriction. Indeed, it is core to their design that they do not oblige states temporarily to criminalise activities: they oblige them to make permanent changes to their legal corpus and to their modes of working; they put in place committees, offices, executives, etc. at UN level that have time-limited mandates, but which are always renewed; they embed permanently 'soft' international institutions (that is, not international organisations having the characteristics of IOs in international law) like the US-established Global Counter-Terrorism Forum in international law and transnational governance by expressly referring to them and their soft-law standards in Security Council resolutions; they permanently and seriously shift and distort the activities of the international community and the funding of the United Nations ${ }^{118}$ etc. Given this, I read with particular interest Floyd's consideration of the notion of 'the exception' (p. 58 et seq).

Floyd argues that ' $[\mathrm{w}]$ ithout the exception ... serious questions arise about what separates securitisation from politicisation' (p. 59) and thus argues that just securitisation theory is 'concerned only with securitisation in its exceptional form' (p. 60). This she defines by reference to law, arguing that

the exception refers not to the suspension of law altogether, but rather to the situation when (new) emergency laws are passed/put into action and/or new emergency powers are granted that seek to govern the insecurity/crisis situation, or when a state's existing security apparatus is employed to deal with issues that are either new, or that it has not dealt with previously (p. 61)

While this, I think, captures well domestic securitisations of terrorism in the past (including in the United Kingdom), I wonder at the insistence on the notion of 'emergency' laws and 'emergency' powers when seen against contemporary counterterrorism. This is not only because the modes of transnational counterterrorism are clearly not 'emergency' (inasmuch as they are not intended to be temporary), but also because the notion of 'emergency' even in domestic counterterrorism is increasingly under pressure ${ }^{119}$ given the well-established concretisation of counterterrorism laws, powers, technologies, and activities and emergence of what I have previously called 'the counter-terrorism state ${ }^{120}$ in which counterterrorism is bedded down as an expansive, permanent, and encompassing mode of governance. This is underpinned, accelerated, and made inevitable by transnational counterterrorism because, among other things, of its insistence on permanence, its institutional sprawl, its budgetary hold on the UN's agenda, its desirability to hegemonic states, its enforcement mechanisms, its focus on 'capacity building', and its construction of an ever-hardening web of transnational counterterrorism that involves international,

\footnotetext{
${ }^{117}$ See, for an institutional starting point, UN Secretary General, Plan of Action to Prevent Violent Extremism (2015), UN Doc. A/70/674.

${ }^{118}$ For an excellent analysis, see Ali Altiok and Jordan Street, A Fourth Pillar of the United Nations? The Rise of Counter-Terrorism (Saferworld, 2020).

${ }^{119}$ See, for example, Alan Greene, Permanent States of Emergency and the Rule of Law: Constitutions in an Age of Crisis (Oxford, UK: Hart Publishing, 2018).

${ }^{120}$ Jessie Blackbourne, Fiona de Londras, Lydia Morgan, Accountability and Review in the Counter-Terrorist State (Bristol, UK: Bristol University Press, 2019), esp. ch. 1.
} 
regional, national, industry, civil society, policing, intelligence, military, and development organisations and agencies.

All of this also makes it unamenable to desecuritisation; there is no turning back from the juggernaut of transnational counterterrorism, and even if there were the non-emergency nature of its normative products are such that the legal landscape is permanently changed so that the content of rights has been recalibrated downwards, ${ }^{121}$ the nature of international cooperation has been made data-rich and embedded, and non-security actors at the international level (like UNESCO, ${ }^{122}$ the ICAO, ${ }^{123}$ or $\mathrm{UNDP}^{124}$ ) have been shifted into a securitised register that seems impossible to dislodge. ${ }^{125}$

On my reading of The Morality of Security this means one of two things: either transnational counterterrorism does not constitute a securitisation (because of its non-adherence to the paradigm of the 'exception' and non-amenability to desecuritisation), or if it does that transnational counterterrorism is outside of the sights of just security theory because of its exclusive attention on the exception. Either of these conclusions would, I think, be problematic.

The former would suggest that this is 'mere' politicisation, but the effect of transnational counterterrorism is to stymie politicisation at the national level. Indeed, as I have written before, ${ }^{126}$ that is a feature of transnational counterterrorism, with states 'jumping scales' from national to transnational in order to create irresistible impulses to legal and operational action in the domestic sphere. The latter conclusion would suggest that this enormous project of transnational counterterrorism cannot be subjected to the rigour of the moral and ethical test of just securitisation that Floyd so convincingly outlines in The Morality of Security and thus is either irredeemably unjust, or simply not attended to at all. Given the (sometimes under-appreciated) implications of transnational counterterrorism for rights, capital, politics, data, policing, and freedoms in everyday life, it seems a significant omission for it to be beyond the purview of just securitisation theory.

On my reading, then, attention to the transnational scales of securitisation in counterterrorism and their complex and diffuse implications at 'subordinate' scales raises new questions about the scope, reach, and adequacy of how we understand securitisation and the moral and ethical questions that it raises. Floyd can hardly be criticised for not having attended to this; transnational counterterrorism is sprawling, often opaque, multipronged, and ever-shifting. That is its mode of operation. ${ }^{127}$ That is what makes our engagement with it so urgent, and my curiosity for how just securitisation theory might be developed better to deal with it so ripe, having had the pleasure of reading this provocative and ambitious book.

\footnotetext{
${ }^{121}$ I wrote about (attempted) downward recalibration in Fiona de Londras, Detention in the 'War on Terror' (Cambridge, UK: Cambridge University Press, 2011).

${ }^{122}$ For example, UNESCO chairs a working group of the United Nations Global Counter-Terrorism Coordination Compact, and develops and provides curricula and learning materials intended to help prevent violent extremism conducive to terrorism.

${ }^{123}$ For example, the ICAO required states to establish Advance Passenger Information systems, following the Security Council requiring the ICAO to work with the Counter-Terrorism Committee to address terrorist risks to civil aviation: Security Council Resolution 2309 (2016).

${ }^{124}$ For example UNDP engages in significant work with the Office of Counter-Terrorism to prevent violent extremism as part of its development work.

${ }^{125}$ See generally the analysis in Altiok and Street, A Fourth Pillar of the United Nations?

${ }^{126} \mathrm{de}$ Londras, 'Politicisation, law and rights in the transnational counter-terrorism space'.

${ }^{127}$ de Londras, 'Transnational counter-terrorism'.
} 


\section{Not necessarily securitisation, not completely security: Locating 'just securitization theory' in the logics of security}

Paul Roe

Department of International Relations, Central European University, Vienna, Austria

In The Morality of Security, Rita Floyd sets out to detail a set of conditions according to which actors are justified in deploying 'emergency measures' in the face of threats to their security. In setting out these conditions, Floyd's work is meticulous in addressing a wide range of ethically informed concerns; from the nature of threats, through questions of the referent, to the intentionality of actors. In this short piece, my aim is not so much to take issue, at least not directly, with the criteria put forward by Floyd in defining a just securitisation theory (JST). Rather, my goal is to show, and to take some issue with, why these criteria come about in the first place. In other words, why, for Floyd, does securitisation (arguably better read as 'security') need to be legitimated to begin with? In doing so, I want to make clear two main points of contention: the first is that Floyd's understanding of securitisation; in particular, the matter of the 'exception', is one that reflects its 'outcome' and not its 'process'. As a result, Floyd proceeds with a characterisation of emergency measures that fails to separate properly securitisation from politicisation. The second is that securitisation (security) conceived of solely as a set of exceptional (read harmful, possibly violent) practices unduly narrows the very conception of security itself. I am in no doubt that this will come as no surprise to Floyd. Nevertheless, I still think it's important to shed light on how Floyd's securitisation operates in accordance with just a single, so-called security 'logic': what previously has been referred to as to the 'logic of war', and what, similarly, here is set out as that of exception; rather than, as I present here, three security logics: 'elimination' (war/exception), 'management', and 'transformation'. First, though, to securitisation itself.

In a previous engagement with the emerging debate of the ethics of security, I made the distinction between securitisation as 'process' and securitisation as 'outcome'; ${ }^{28}$ that is, to say, between how security policy is formulated and how policy translates into actual behaviour. In doing so, I noted how the position of the Copenhagen School (CoS) itself, or, perhaps more accurately, Ole Wæver himself, was bound up ostensibly with the matter of process. In their original formulation of the concept, the CoS note that securitisation is the result of the 'failure to deal with issues as normal politics', with normal given meaning by reference to the 'routine procedures' of politics. ${ }^{129}$ In the context of liberal democratic states (where it's evident that the CoS' theorising derives from), ${ }^{130}$ normal politics equates with how policymaking; the legislative process, takes place in accordance with established mechanisms. As I have characterised this, procedures are marked by 'debate and deliberation': ${ }^{131}$ the legislature and other bodies takes its time to scrutinise the executive. With a securitised issue, though, the process is not normal, but

\footnotetext{
${ }^{128}$ Paul Roe, 'Is securitization a "negative" concept? Revisiting the normative debate over normal versus extraordinary politics', Security Dialogue, 43:3 (2012), pp. 249-66.

${ }^{129}$ Buzan, Waever, and de Wilde, Security, p. 29.

${ }^{130}$ Claire Wilkinson, 'The Copenhagen School on tour in Kyrgyzstan: Is securitisation theory useable outside of Europe?', Security Dialogue, 38:5 (2007), pp. 5-25; Juha Vuori, 'Illocutionary logic and strands of securitization: Applying the theory of securitization to the study of non-democratic political orders', European Journal of International Relations, 14:1 (2008), pp. 65-99.

${ }^{131}$ Roe, 'Is securitization a negative concept?', p. 251.
} 
'extraordinary'. In the face of an existential threat, though, the CoS presume that there will be no time for the normal process of debate, deliberation, 'we don't have time for talking about this now. We must act and act quickly!'. Accordingly, Jef Huysmans ${ }^{132}$ talks about how securitisation necessitates speed against the relative slowness of normal politics. To refer once more to my previous characterisations: the extraordinary politics of securitisation is rather about 'silence and speed. ${ }^{133}$ For many, this is why securitisation comes across very much as a kind of 'panic politics'.

Set against this, Floyd's engagement with the notion of the 'exception' also notes how many scholars have come to equate securitisation with the Schmittian logic of 'executive unilateralism', where the sovereign is entitled to suspend the existing rule of law; pretty much akin to riding rough shod over the deliberative processes of the legislature. ${ }^{134}$ But Floyd chooses not to see exception in this way. For her, the sovereign (executive) should not be seen as above the law. Instead, Parliament (the legislature) passes new laws and grants new powers to tackle the impending emergency. On this particular point, I have, and still do very much agree with Floyd's view as to how a process of securitisation invariably proceeds. Nevertheless, this puts Floyd's securitisation very much out of keeping with Wæver's original 'bad for democracy' rendering of the concept; after all, it can't be bad if Parliament continues to play a prominent role in the passing of legislation.

Explicit in the endeavour of formulating a set of criteria for legitimating certain acts is the presumption that, ordinarily, such acts are illegitimate; they are, in some way, bad. JST defines under what circumstances acts of securitisation are permitted: how securitisation can be 'rescued' from its badness. But if not in accordance with process, from where does its badness come? This is hinted at when Floyd remarks: 'JST is only interested in securitization as the exception. Throughout this book I refer to exceptional security action as security measures. ${ }^{, 135}$ Exception, then, lies not in process: to say again, exception refers to (emergency) measures. It lies in 'outcome'. This is given further expression when Floyd makes clear that 'my interpretation of securitization is comparable to war.' ${ }^{136}$ Although securitisation might take place short of actual war, and, this is the crucial point, its measures will certainly be also harmful to others (deportation, detention, or incarceration) and possibly in a most violent way (torture).

Admittedly, Floyd is careful to note that securitisation 'takes many forms', ${ }^{137}$ for example, referring to Maria Julia Trombetta's ${ }^{138}$ work on environmental security, where Trombetta rejects security practices as being about the exception. But this still misses the point that, in terms of the original CoS perspective, exception is not to be understood in terms of outcome (practices), but process (security formulations). Moreover, and maybe more importantly, Floyd justifies the criterion of exception as that which separates most clearly securitisation from politicisation. ${ }^{139}$ Understood as outcome, though, it arguably doesn't. A politicised issue; something that works in accordance with debate and deliberation, might well produce the same kind of emergency measures (harm, violence) as that of a securitised issue. Put simply, issues that are handled slowly by a legislature can also result in policies that sanctions bad things! Is what we are left with, then, simply a focus on 'doing' bad things, instances of policy manifesting itself to the (mostly) physical detriment of others?

In moving from process to outcome like this, Floyd's position on securitisation comes perilously close to that taken by several, more Poststructuralist scholars. Again, drawing on a largely

\footnotetext{
${ }^{132}$ Jef Huysmans, 'Minding exceptions: Politics of insecurity and liberal democracy', Contemporary Political Theory, 3:3 (2004), p. 332.

${ }^{133}$ Roe, 'Is securitization a negative concept?', p. 252.

${ }^{134}$ Floyd, The Morality of Security, p. 60.

${ }^{135}$ Ibid., p. 64, emphasis added.

${ }^{136}$ Ibid.

${ }^{137}$ Ibid., p. 59.

${ }^{138}$ Maria Julia Trombetta, 'Rethinking the securitization of the environment: Old beliefs, new insights', in Balzacq (ed.), Securitization Theory, pp. 135-49.

${ }^{139}$ Floyd, The Morality of Security, p. 59.
} 
Schmittian rendering of the political, writers such as Claudia Aradau, ${ }^{140}$ Andreas Behnke, ${ }^{141}$ and Mark Neoclous $(2011)^{142}$ view securitization/security as necessarily constituting and delineating bodies of us and them, friend and enemy. This is done by way of antagonism, and one that is invariably hostile. Indeed, so hostile that for some it comes to equate with fascism ${ }^{143}$ and even Nazism. ${ }^{144}$ This extreme characterisation aside, this position nonetheless assumes that securitisation/security is inherently about the production of winners and losers, security-haves and security have-notes, those rendered safe and those rendered abject. For the likes of Aradau, the ethical solution to the badness of security is to escape from its very condition, an emerging position in the literature that can be called 'anti-security'. To get rid of the bad we have to get rid of the security too! For Floyd, security is not to be escaped. Security (securitisation) is rather to be rescued: through the lens of JST, harm (bad) can be permitted under certain conditions.

Another way of putting all of this is to claim that security/securitisation has an essential logic to it, that of the exception, that of war. In this regard, Floyd's JST is subject to the same kind of critique that can also be levelled against the work that Stefan Elbe has done on the securitisation of HIV/AIDS. Differently to Floyd, Elbe asks not what can legitimate emergency measures, but what justify a securitisation in the first place. Still, with Elbe, what predicates the 'dangers' and 'benefits' of securitising AIDS, and thereby constitutes how start with a balancing of the pros and cons, is a similar assumption about logic. For example, in noting how a securitisation of AIDS will likely push 'responses to the disease away from civil society toward ... military and intelligence organizations, which also possess the power to override human rights and civil liberties'. ${ }^{145}$ Elbe, like Floyd, like the Poststructuralists, assumes a "threat-defense" logic inherent in the securitization of HIV/AIDS, ${ }^{146}$ where threat-defence can undoubtedly be read as exception/war. To labour the point perhaps, the requirement for, and the nature of the moral calculation of securitisation derives from an understanding of just a single, and unavoidable security logic. But security/securitisation does not have an inherent logic. Such a formulation is simply overly deterministic. In fact, security has at least three logics: in addition to exception/war; what I choose to call the logic of 'elimination', are also those of 'management' and 'transformation'.

With the logic of elimination, the purpose of security practices is simply to get rid of the threat. Although not necessarily taking the exact form of war as it is traditionally understood (as armed conflict) elimination is about vanquishing your enemy; or at least depriving your enemy of its ability to threaten in a certain way. And, to restate somewhat, in JST, it relates to harmful, perhaps violent forms of behaviour.

Thinking about the management of threat has derived largely from the relatively recent engagement of security studies with the notion of risk. Floyd engages with risk primarily with a view to tackling the question of future threat, in particular, with the consideration of 'prevention/preventive war' as a possible candidate for a just securitisation. ${ }^{147}$ Here, I don't want take issue with how Floyd deals with prevention in this regard. Rather, the intention is to make clear how the idea of risk (as opposed to threat) can bring with it the logic of management. As Floyd demonstrates from her discussion of the likes of Olaf Corry ${ }^{148}$ and Mikel Vedby

\footnotetext{
${ }^{140}$ Claudia Aradau, 'Security and the democratic scene', Journal of International Relations and Development, 7:4 (2004); Claudia Aradau, Rethinking Trafficking in Women: Politics out of Security (Basingstoke, UK: Palgrave Macmillan, 2008).

${ }^{141}$ Andreas Behnke, 'No way out: Desecuritization, emancipation and the eternal return of the political: A reply to Aradau', Journal of International Relations and Development, 9:1 (2006), pp. 62-9.

${ }^{142}$ Mark Neoclous, 'Inhuman security', in David Chandler and Nik Hynek (eds), Human Security: Rethinking Emancipation and Power in International Relations (London, UK: Routledge, 2011).

${ }^{143}$ Aradau, Rethinking Trafficking in Women, pp. 162-3.

${ }^{144}$ Neoclous, 'Inhuman security', p. 35.

${ }^{145}$ Stefan Elbe, 'Should HIV/AIDS be securitized? The ethical dilemmas of linking HIV/AIDS and security', International Studies Quarterly, 38:3 (2006), p. 128.

${ }^{146}$ Ibid., p. 130, emphasis added.

${ }^{147}$ Floyd, The Morality of Security, pp. 94-7.

${ }^{148}$ Olaf Corry, 'Securitisation and riskification: Second-order security and the politics of climate change', Millennium: Journal of International Studies, 40:2 (2012), pp. 235-58.
} 
Rasmussen, ${ }^{149}$ risk is about the future. But, as opposed to what might be described as a future 'threat', a risk is less tangible. Not only are risks also located in some (quite unspecified) future time, their origin is also unknown. To give a prominent example: When the US- and UK-led coalition invaded Iraq in 2003, a first reason given was indeed about threat: Saddam Hussein's future acquisition of further WMD capabilities posed an existential threat to his neighbours and to others. Here, preventive war against the Iraqi regime removes this possibility. A second reason, though, was that future Iraqi WMD capability also brought with it the risk of its diffusion to transnational terrorist organisations. Again, while something also for the future, from which actor(s) this might come also wasn't known (not a Rumsfeld 'known unknown', but an 'unknown unknown'!). Importantly, then, while the same in its actual form (war), the conflict itself thus proceeds on the basis of two different logics; not only that of elimination (the Iraqi threat) but of management too (the risk of terrorist attack). Put simply, because risk is unknown in both source and temporality it cannot be directly gotten rid of. Instead, its 'conditions of possibility for harm' can be governed, or managed. ${ }^{150}$

Crucially, though, the logic of management can also be found in forms other than that of offensive military action. Similar in purpose to where proponents of risk talk about resilience, other (more traditional) strategic concepts like deterrence by denial and non-offensive defence (NOD) seek to manage, not eliminate threat. ${ }^{151}$ For instance, Switzerland's strategy of the mobilisation of mass reservists accepts that whatever (external military) threat it is facing cannot/should not be defeated by offensive measures. Instead, the costs of attacking and occupying the country are raised dramatically by the prospect of encountering tens upon thousands of citizens armed to defend their territorial integrity. In doing so, NOD/deterrence by denial does not seek the elimination of threat, but its management in reducing the likelihood of its very manifestation.

Similarly, in my past exchange with Matti Jutila over the securitisation of minority rights, I noted how, with a securitisation that managed potentially conflictual relations between majority and minority, 'measures are put in place that reduce, or even effectively rule out, the recourse to emergency politics' [measures]. ${ }^{152}$ In this particular context, the provision of multinational federalism, rather than trying to preclude the possible eventuality of succession by persecuting/suppressing the minority (elimination), such an autonomous arrangement instead seeks to manage its future conditions of possibility. Will multinational federalism be seen by everyone involved as something positive? Perhaps not. Still, it surely does not represent the kind of bad security practices that need to be rescued by virtue of JST.

The third logic of security is transformation. Unlike the logic of elimination and, in part at least, the logic of management also, transformation is invariably bereft of the kind of harm that characterises Floyd's usage of securitisation. With the logic of transformation, a security issue is tacked in such a way that the production of danger is radically reconstituted. Bill McSweeney's rendering of positive security exemplifies how this logic works; in particular, in his articulation of the difference between what he calls 'social control' and 'social order'. For social control, this centres 'on the perception of external threat and the organization of material resources to remedy the vulnerabilities exposed to the perceived aggression'. ${ }^{153}$ For social order, though, emphasis is placed on security as the property of a relationship: being secure cannot experienced at the expense of another (eliminating the threat) It is the security of social relations. ${ }^{154}$ This is

\footnotetext{
${ }^{149}$ Mikel Vedby Rasmussen, The Risk Society at War: Terror, Technology and Strategy in the Twenty-First Century (Cambridge, UK: Cambridge University Press, 2006).

${ }^{150}$ Corry, 'Securitisation and riskification', quoted in Floyd, The Morality of Security, p. 95.

${ }^{151}$ See, for example, Barry Buzan and Eric Herring, The Arms Dynamic in World Politics (Boulder, CO: Lynne Rienner, 1998).

${ }^{152}$ Paul Roe, 'Reconstructing identities or managing minorities? Desecuritizing minority rights: A response to Jutila', Security Dialogue, 37:3 (2006), p. 433.

${ }^{153}$ Bill McSweeney, Security, Identity, and Interests: A Sociology of International Relations (Cambridge, UK: Cambridge University Press, 1999), p. 176.

${ }^{154}$ Ibid., p. 782.
} 
close to how Lene Hansen, for example, has thought about desecuritisation as 'rearticulation'; 'fundamental transformations of the public sphere including a move out of the friend-enemy distinction'. ${ }^{155}$ Put simply, transformation goes beyond both elimination and management in the sense that it changes (for the better) the very relationship between self and other.

To take a simple scenario of crime to sum up the difference between how the three logics operate: in an inner-city setting, a wave of burglary has sprung up perpetrated mostly by disaffected young people. With the logic of elimination, police identify and arrest the burglars with a view to successful prosecution; prison sentencing eradicates the source of threat. With management, homeowners take measures to try to ensure that any possibly break-ins will be deterred (big fences, CCTV cameras, alarm systems, and the like). The burglars don't disappear (into jail). Still, the possibility for harm (break-ins) is still addressed. And finally, with transformation, rather than simply accepting the reality of crime as it is, the young people in question are introduced to a life without the potential for criminality; for example, youth centres might be opened that help to provide certain skills for meaningful employment. And, in this way, security behaviour indeed reflects the kind of property of a relationship that McSweeney conceives of.

All in all, what this demonstrates is that a single logic (war/exception) belies the fact that security practices often take place without the kind of (violent) harm that JST endeavours to legitimise. And while it may well be true that 'not all securitizations have the same degree of impact on the world and people around them', ${ }^{156}$ it is equally, if not more so that, as McSweeney puts it so well: 'most of us do not live our lives in the terror of the London Blitz. ${ }^{\text {'157 }}$ In much the same way that McSweeney acknowledges the necessity of social control, harmful means are indeed sometimes required to eliminate/manage security threats. This is not denied. But, for many people around the world the reality of their lives in being secure is not one of violence.

JST (as I'm sure others will be commenting on extensively) takes many of its cues from just war theory (JWT), and, like JWT, concentrates on a fairly specific set of practices. And these practices are defined by the perpetration of harm, often violent in nature. Practices that raise serious ethical questions? For sure. But, at the same time, practices that are too narrowly conceived to constitute a morality of security. Moreover, as a theory of just 'securitisation' (not security), in understanding exception in relation to outcome, not process, Floyd's work fails to properly differentiate politicisation from securitisation: legislatures can indeed operate in accordance with debate and deliberation; doing 'normal' politics, but still end up formulating policies that require the prosecution of violence. Is it, then, about a just securitisation? Or quite possibly more a theory of just harm only?

\title{
The morality of security: A reply to critics and where to from here
}

\author{
Rita Floyd \\ Department of Political Science and International Studies, University of Birmingham, UK
}

\section{Introduction}

Although a little unnerving, any scholar can only dream of a symposium dedicated to their work. Especially in a leading journal and featuring top scholars from a range of disciplines. I am very grateful to the editors, especially to Professor Edward (Ted) Newman for giving me this opportunity, as well as to the four respondents for their thoughtful engagement with my work.

\footnotetext{
${ }^{155}$ Lene Hansen, 'Reconstructing desecuritisation: The normative-political in the Copenhagen School and directions for how to apply it', Review of International Studies, $38: 3$ (2012), p. 543.

${ }^{156}$ Floyd, The Morality of Security, p. 59.

${ }^{157}$ McSweeney, Security, Identity, and Interests, p. 153.
} 
Coming from four different disciplines (security studies, law, moral philosophy and criminology, respectively) respondents stress dissimilar issues. International Relations scholar and a prolific voice in securitisation studies, Paul Roe questions my reading of securitisation vis-à-vis the Copenhagen School's as well as clarity on the distinction between securitisation and politicisation. Law Professor Fiona de Londras ponders the applicability of just securitisation theory (JST) ${ }^{158}$ to transnational counterterrorism much of which is expressed as law. The philosopher Jessica Wolfendale tests the theory against a case of non-state actor securitisation, specifically African Americans' resistance against white supremacy in the United States. And finally Oxford-based criminologist Ian Loader draws parallels between securitisation and moral panics (which often ensue after egregious crimes), with the aim to question JST's purported action-guiding and emancipatory potential.

In what follows I will engage with each of the responses in turn. I defend JST from criticism only where I perceive misunderstandings or misrepresentations. Given that I am especially interested in building up ethics and security as 'just securitisation studies', where numerous scholars develop and refine principles of just securitisation and desecuritisation, ${ }^{159}$ I conclude by reflecting on pathways to further research emerging from the four contributions.

\section{Down to business}

Writing from within security studies Paul Roe takes issue with JST's conception of securitisation as the exception. He makes two points. First, understanding securitisation as the exception is too narrow, after all securitisation can also refer to the management of threat(s), and even to threat transformation. Second, a focus on emergency measures fails to sufficiently separate securitisation from politicisation, because politicisation too can result in harmful outcomes. In the following I will deal with these points at some length. Coming as it does from my home discipline, this kind of criticism has the power to delegitimise my attempt to combine securitisation and ethics, even if this is not Roe's intention.

To my mind, Roe's two statements cannot both be true at the same time. Surely an (overly) narrow conception of securitisation as the exception ('the abnormal'), distinguishes the same adequately from politicisation (that is, the normal). Undeniably politicisation too can lead to harmful measures, but that does not render a politicisation a securitisation, because it does not come with a threat articulation (securitising move) attached.

I wonder if Roe's problem with my work here is more adequately captured by my - for his taste - not differentiating enough between securitisation (which he equates with elite empowerment) and security measures (which I equate with successful securitisation). ${ }^{160}$ Note that he takes issue with my focusing almost exclusively on - in his terminology - 'the outcome' of securitisation (actual behaviour) not on 'process' (by which he means how security policy is formulated). This objection also comes through in the title of his response. My focus, he argues, is contra Ole Wæver and the Copenhagen School whose conception of securitisation is heavily loaded in favour of process, hence - he argues - their view that securitisation is bad for democracy. Without a doubt, part of the reason for the Copenhagen School's, or better Wæver's, negative view of securitisation is its equation with de-democratisation. But does this mean that he and the Copenhagen School are process-orientated, to a degree that securitisation is elite empowerment? I think not. For one thing, de-democratisation is not solely about how decisions are made, but it does involve

\footnotetext{
${ }^{158} \mathrm{JST}$ is my version of a theory of just securitisation; other version are possible and welcome.

${ }^{159}$ Floyd, 'The promise of theories of just securitisation'.

${ }^{160}$ I hold that securitisation exists at the point of audience acceptance, but that it 'succeeds' when emergency measures are adopted. Rita Floyd, 'Extraordinary or ordinary emergency measures: What, and who, defines the "success" of securitization?', Cambridge Review of International Affairs, 29:2 (2016), pp. 677-94.
} 
extraordinary measures that break with fundamental rights and civil liberties definitive of liberal democracies. For example, infringements of the right to privacy due to surveillance. ${ }^{161}$

For another thing, it is questionable whether the empowerment of state executives and other elites is a reflection of securitisation's process? Or put differently, is Roe right to locate securitisation with who makes decisions, and with the how decisions are made not with the nature of actions? To my mind Roe's differentiation between process and outcome of securitisation is not altogether helpful or even possible. After all, elite empowerment is an outcome of securitisation understood as speech act + audience acceptance. Moreover, Wæver himself lists 'the logic of necessity, the narrowing of choice [and] the empowerment of a smaller elite' as 'inevitable negative effects [which is to say outcomes] of any securitization'. ${ }^{162}$ In short, I don't think that Roe is correct when he argues that by focusing on exceptional measures my framework is far removed from the Copenhagen School, while I also do not think that it is difficult to tell securitisation focused on exceptional security practice apart from politicisation.

But let us examine what would happen if securitisation was tantamount to process in the way Roe sees it (bearing in mind here that this is permissible, as no one owns the rights to a definition of securitisation). It seems to me that if securitisation equates to the way decisions are made as opposed to adoption of extraordinary measures, then a corresponding just securitisation theory could more easily accommodate Roe's other security logics, above all management (transformation - as far as I can see - lies with desecuritisation).

Fiona de Londras, in her contribution to the symposium, offers a case of securitisation as management. Having worked on counterterrorism and the implications for rights and security at the domestic level in the past, ${ }^{163}$ de Londras' recent work is on transnational counterterrorism. ${ }^{164}$ In short, United Nations and the UN Security Council orchestrated rules, laws, regulations, and institutions that dictate and adjudicate counterterrorism policy at lower levels of analysis. Given that many of these measures do not meet the threshold of the exception, but are nevertheless status quo altering and often of dubious value, de Londras argues that we need an ethical approach to securitisation as management. Alas, JST with its fixation on exceptional measures cannot deliver. Point taken.

I also agree with de Londras and Roe that expressions of securitisation as management in addition to securitisation as exception would offer a more holistic and accurate view of securitisation in practise. Indeed in the Morality of Security, ${ }^{165}$ I note my own somewhat disorderly stance whereby I - in other writings - recognise and work with securitisation below the level of the exception. ${ }^{166}$ And, yet in the book I work only with securitisation as the exception. The reason for this is that more harmful securitisations throw up the question of morality more acutely than less harmful securitisations. In short, in the book, as a first work on the ethics of securitisation, I am dealing with the hard cases that will be the most difficult to justify. This is not to deny that a morality of securitisation as management also is required. Given, however, that greater harm requires higher thresholds of justification, I am unsure whether the different logics of security can be reconciled into a singular just securitisation theory.

That JST works for exceptional securitisation is shown well in Jessica Wolfendale's contribution. Taking on the politically loaded topic of the contemporary securitisation of white supremacy by African Americans she applies the theory to a non-state actor. She finds that African Americans, who are - like all morally innocent (in the relevant sense) human beings - a just

\footnotetext{
${ }^{161}$ Conor Gearty, Liberty \& Security (Cambridge, UK: Polity Press, 2013); Jeremy Waldron, Torture, Terror and Trade-Offs: Philosophy for the White House (Oxford, UK: Oxford University, 2010), pp. 26-7.

${ }^{162}$ Wæver, 'Politics, security, theory', p. 46

${ }^{163}$ De Londras, Detention in the 'War on Terror'.

${ }^{164}$ Fiona de Londras, The Practice and Problems of Transnational Counter-Terrorism (Cambridge, UK: Cambridge University Press, 2021).

${ }^{165}$ Floyd, The Morality of Security, p. 59.

${ }^{166}$ After all, if securitisation is decided by actors, then the nature of emergency measures cannot be stipulated by scholars.
} 
referent object of securitisation, are objectively existentially threated by the manifold threat of white supremacy (manifest, in part as structural racism). She further shows that here a securitising response (involving armed resistance, violent protest, etc.) is made on the basis of right intention and that securitisation is likely to satisfy macro-proportionality, as it is unlikely to cause greater harm than it seeks to solve. To be sure, in line with the theory Wolfendale does not call for securitisation, let alone incite violence, instead she examines whether securitisation would be morally permissible. As such, Wolfendale does a great job in bringing the theory to life through a case study, something the book lacks. ${ }^{167}$

Wolfendale ends by considering reasonable chance of success, which is criterion five of the just initiation of securitisation. Wolfendale begins her discussion by looking at which, securitisation or less harmful alternatives (notably politicisation), has the best chance of satisfying just cause. She argues that given that less harmful measures have failed to address the threat of white supremacy, securitisation seems morally permissible. Up to this point her analysis is in line with what JST prescribes. Unfortunately hereafter a misunderstanding creeps in. Hence Wolfendale concludes that JST would consider securitisation by significantly less powerful actors (notably, state-based non-state actors taking on states) unjustified, because - due to the power imbalance - it cannot succeed. That is, it cannot avert the threat. What Wolfendale fails to see here, however, is that in JST reasonable chance of success does not refer to such an absolute prospect of success in satisfying just cause. Instead securitisation's chance of success is judged relative to those of less harmful options (politicisation (read: normal measures) and inaction). In other words, contra Wolfendale's suggestion, JST can accommodate supposedly 'futile' resistance.

As Wolfendale herself suggests, however, success can be understood in different ways. Meaning that futility is relativised. The philosopher Daniel Statman has argued that 'success [in self-defence ] depends on the goal of the defensive act." ${ }^{168}$ If one such goal is the protection of honour even unsuccessful harmful acts (in terms of achieving the just cause) are not futile. In Statman's words:

Whenever victims of aggression are overwhelmed by an aggressor but, nonetheless find the courage to rise against him through some form of determined resistance, however hopeless, they are thereby reaffirming their honor ... Hence, such actions necessarily succeed (at least partially ...) in achieving their goal. ${ }^{169}$

From this position, African American resistance to white supremacy is not futile.

Wolfendale's contribution is also, and perhaps unknowingly seeing that she is not an IR scholar, a statement on the recent securitisation and racism controversy. In 2019 the Copenhagen School's securitisation theory was - in an article by Alison Howell and Melanie Richter-Monpetit published in Security Dialogue $e^{170}$ - labelled racist and 'deemed unsalvageable and in need of ejection from security studies'. ${ }^{171}$ As Dan Nexon and Patrick Taddeus Jackson so poignantly observe this charge affects everyone working with securitisation theory. Thus to work with securitisation theory could now be interpreted as aiding or abetting racists, if not worse. In showing that JST can support the fight against racism and racial inequality by non-state actors, Wolfendale's response wards off a charge of racism.

\footnotetext{
${ }^{167}$ To be sure, I am not necessarily agreeing with Wolfendale's points, only that she effectively demonstrates how JST can be put to work on a concrete example.

${ }^{168}$ Daniel Statman, 'On the success condition for legitimate self-defense', Ethics, 118:4 (2008), pp. 659-86 (p. 668 )

${ }^{169}$ Ibid., p. 679.

${ }^{170}$ Alison Howell and Melanie Richter-Montpetit, 'Is securitization theory racist? Civilizationism, methodological whiteness, and antiblack thought in the Copenhagen School', Security Dialogue, 51:1 (2020), pp. 3-22.

${ }^{171}$ Daniel Nexon and Patrick Taddeus Jackson, 'It isn't just about Wæver and Buzan', The Duck of Minerva (27 May 2020), available at: $\{$ https://www.duckofminerva.com/2020/05/it-isnt-just-about-waever-and-buzan.html\}.
} 
On the basis of the three responses discussed so far I am pleased to surmise that, notwithstanding various limitations, JST works for scholars already interested in ethics and security. But JST's target audience is not 'merely' scholars, the theory is explicitly action-guiding. The question is, does this amount to more than wishful thinking? Professor Ian Loader raises this in his contribution to the symposium, when he argues that securitising actors will - in times of moral panic, which he argues share much in common with securitisation - not have the time for ethical evaluation of what they are about to do; second they may not recognise that they are engaged in securitisation and consequently deny applicability of moral principles to their situation. The latter point, I think, draws perhaps too heavily on moral panics that are superimposed on situations by outsiders with actors unaware that they are panicking. Securitisation, by contrast is a more conscious activity, at least in the linear way I see it. Loader's time constraint point, by contrast, is a more substantial critique. I will return to it in due course.

Another issue raised by Loader concerns my claim that JST has emancipatory potential. Contra my suggestion he argues the theory is a politics of radical limitation, not a politics of transformation'. ${ }^{172}$ Clearly, for Loader, emancipation via securitisation is impossible - this is not far removed from others. Claudia $A_{\text {radau }}{ }^{173}$ seeks emancipation away from security, while Ken Booth seeks emancipation away from securitisation. ${ }^{174}$ But does this have to be so? Are securitisation and emancipation incompatible in the way these analysts suggest? The answer, it seems to me, depends on what one means by emancipation. If Emancipation means freedom from legal, political, or social controls it is quite possibly incompatible with securitisation, however, if emancipation means freeing people from poor security practice towards a more just and enlightened security practice it is compatible. Clearly I mean emancipation, not Emancipation.

While Loader is sympathetic to my aims in the book, I suspect he would be sceptical even of JST's (small e) emancipatory potential because he thinks that urgency negates a role for ethics in emergencies. ${ }^{175}$ This may be true of some cases, but it isn't true of all cases. In Britain, for example, a fortnight passed between Boris Johnson first telling people to stay at home for seven days if experiencing symptoms of coronavirus, and lockdown measures legally coming into force. In liberal democracies in general, there will always be some deliberation and weighing up of responses, this much is captured by the significance securitisation scholars attribute to the audience.

But there is more, whether or not ethical considerations are likely to feature in key moments of crisis also depends on how established they are in any given society. The laws and morality of war - at least at the level of rhetoric - are well established globally. Governments are likely to seek a UN Security Council mandate for war, and when they fail to obtain one they usually try very hard to justify the war with reference to other moral or legal factors. ${ }^{176}$ Notwithstanding the fact that there is much abuse of the legal norms and moral principles of war, the same still makes a positive difference. The just war tradition allows meaningful and informed discussion about the legality and/or morality of different wars including critique and holding leaders to account. I believe that if we as scholars work systematically on the ethics of securitisation, a similar positive effect is within reach. Thus, if JST informed practitioners rhetoric and action, then the media, informed members of the public and other functional actors ${ }^{177}$ could use key concepts to hold securitising

\footnotetext{
${ }^{172}$ Ian Loader, 'Not just securitisation: On the limits of limiting security practices', European Journal of International Security, this Book Review Symposium.

${ }^{173}$ Aradau, 'Security and the democratic scene', pp. 388-413.

${ }^{174}$ Ken Booth, Theory of World Security (Cambridge, UK: Cambridge University Press, 2007); see also Peoples, 'Security after emancipation?'.

${ }^{175}$ Having consulted a number of people on whether anyone distinguishes between small $\mathrm{E}$ and capital e version of emancipation in this way, I am confident it is not common practice. In any case, my apologies if I am ignoring someone's past efforts.

${ }^{176}$ The George W. Bush admistration, for example, linked its controversial strategy of pre-emptive defence in Iraq to the UN charter.

${ }^{177} \mathrm{I}$ have argued elsewhere that functional actors are actors that 'seek to positively or negatively influence the trajectory of securitisation - in which they are not the referent object or the threatener - while it is already underway'. Rita Floyd,
} 
actors accountable for unjust securitisation, making practitioners think harder about securitising in an ethically sound manner. In that way, bit by bit, emancipation away from negative and unjust securitisation can be achieved.

\section{Conclusion: Where to from here?}

The coronavirus pandemic has unsettled the view that desecuritisation is morally superior. At the point of writing, the COVID-19 pandemic has claimed well over five million deaths globally. The number of excess death, coupled with the success of lockdown measures highlights the possibility that securitisation is sometimes morally permissible, if not required. For the ethics of securitisation the pandemic is therefore, somewhat perversely, a boon. ${ }^{178}$ Even if one thinks that the securitisation of COVID-19, or some aspect of it, was unjustified we need to give sound reasons supporting our view that not acting in this way would have been better. JST can help here. The vast majority of reasons against securitisation can be formulated by reference to one or more of the JST's substantive criteria. For instance, the securitisation of COVID-19 in illiberal states has been criticised as unjustified because it was informed by wrong intentions (mainly to legitimate illiberal regimes and/or to boost their reach over society). ${ }^{179}$ While others have raised the issue whether the harm securitisation has caused the economy or specific groups is proportionate to the threat averted. ${ }^{180}$

The fact that COVID-19 is making the scholarly community receptive to thinking about the ethics of securitisation is important, because the idea to develop normative principles of just securitisation and desecuritisation was never meant to be complete with one book, or indeed with the efforts of one person. Roe and De Londras' contributions to this symposium show that other versions of just securitisation theory are possible and necessary, in part, because alternative interpretations of securitisation abound. It seems to me that principles guiding the logic of security as management would elevate issues of procedural justice, including audience consent to security measures. ${ }^{181}$ The key emphasis for a corresponding just securitisation theory would have to be on the democratisation of securitisation. Given this symposium's deliberate emphasis on interdisciplinarily, it is important to note that Ian Loader and Neil Walker's book Civilising Security (2007), would be a good starting point for such efforts. After all Loader and his co-author aim at democratising security by - inter alia - allowing for widespread deliberation on security measures.

Given Loader's back catalogue it is not surprising that Loader's contribution to the symposium points to another issue important for civilising securitisation; namely the building of the right kind of institutions. While Loader focuses on political institutions able to resist securitisation, institution building is not limited to this. Allan Buchanan ${ }^{182}$ has long argued that moral progress cannot be achieved in the absence of relevant institutions. Where the ethics of securitisation is

\footnotetext{
'Securitisation and the function of functional actors', Critical Studies on Security (2020), p. 10, available at: \{DOI: 10.1080/ 21624887.2020.1827590\}.

${ }^{178}$ See also Stephane Beale, 'On the Securitization of Covid-19', Pandemipolitics (2020), available at: \{https://pandemipolitics.net/baele/\} accessed 21 July 2021.

${ }^{179}$ E. Aaron, 'Coronavirus Shows the Need for a Human Rights-Based Approach to Public Health Crises', Freedom House (2020), available at: $\{$ https://freedomhouse.org/article/coronavirus-shows-need-human-rights-based-approach-public-healthcrises\}; Biljana Vankovska, 'Dealing with COVID-19 in the European periphery: Between securitization and "gaslighting"', Journal of Global Faultines, 7:1 (June-August 2020), pp. 71-88; Kenneth Roth, 'How Authoritarians are Exploiting the Covid-19 Crisis to Grab Power' (2020), available at: \{https://www.hrw.org/news/2020/04/03/how-authoritarians-are-exploiting-covid-19-crisis-grab-power\}.

${ }^{180}$ Nathan Alexander Sears, 'The securitization of COVID-19', Global Policy Journal blog (2020), available at: \{https://www. globalpolicyjournal.com/blog/25/03/2020/securitization-covid-19-three-political-dilemmas\}.

${ }^{181}$ This is also in line with Roe's previous work. Paul Roe, 'Actor, audience(s) and emergency measures: Securitization and the UK's decision to invade Iraq', Security Dialogue, 39:6 (2008), pp. 615-35.

${ }^{182}$ Allen Buchanan, Institutionalizing the Just War (Oxford, UK: Oxford University Press, 2018).
} 
concerned we need to consider what kind of institutions could ensure both morally permissible and morally mandatory securitisation. Including, whether or not moral principles can and ought to be translated into legal principles, complete with relevant enforcement institutions (for instance, courts).

De Londras' contribution points to the importance of further work on just desecuritisation. She suggests that the securitisation of transnational terrorism is unamenable to desecuritisation largely because the web of institutions, the bureaucratic sprawl and dependency on counterterrorism budgets is now such that the same underwrites too much activity at relevant levels. In other words, relevant security institutions need transnational counterterrorism. From what de Londras suggests, I take desecuritisation here to be politically challenging, but not impossible. It seems to me that one way to achieve desecuritisation in this case would be to refocus the security agenda to another pertinent real threat or a number of such threats to just referent objects. From a moral point of view, however, it is questionable whether desecuritisation through such normative strategic refocusing is morally justifiable. It certainly seems to be the case that just desecuritisation of (unjust) securitisation as management does not need restorative measures to the same degree as exceptional securitisation, because such securitisations inevitably cause less harm. In short, the question is this: Do all just desecuritisations require that all three of the substantive criteria of just desecurititisation are satisfied?

Wolfendale's contribution usefully demonstrates what scholars can do with JST. To be sure the number of case studies is endless. It encompasses non-state and state actors across all sectors of security. JST could form the central theoretical framework in empirical case studies, while it could also simply complement analytical studies allowing researchers to engage more fully and cognisant with the ethics of securitisation, even if desecuritisation remains their preferred choice.

Wolfendale's contribution also demonstrates how empirical cases serve to test, validate or where necessary - revise criteria set out as part of JST. Undoubtedly, most, if not all of the moral principles advanced in The Morality of Security need further work. Consider that - after decades of scholarly work - the relationship between, for example, proportionality, necessity, and the success condition is not settled. ${ }^{183}$ Indeed, all just war scholars can agree on is that the ethics of war can be determined and that a number of moral considerations are relevant to the moral justification of war. Their combination, relative weighting, and - as the success criterion shows - even their precise meaning is up for grabs.

Finally, Loader's contribution points to the importance of engaging security practitioners into just securitisation studies. If, as I maintain, the aim of the theory is to change the way securitisation is currently practised, researchers must ensure that practitioners actually hear of the theory. Speaking for critical security studies only I think it is fair to say that few theorists make the effort to speak to practitioners. Whatever the reasons for this lacuna, engaging practitioners holds the following promise. First, it will be an opportunity to test the feasibility of JST and to feed forward into the theory possible changes. For example, and to go back to a point made by Loader, it would be interesting to observe how decisions are made, specifically is there usually time to consider ethical issues or not? Second - given JST's emancipatory aim, practitioner engagement must also be seen as an opportunity to export the theory's language, concepts, and - above all - its message to the halls of power.

Fiona de Londras is Professor of Global Legal Studies at University of Birmingham School of Law, and author of The Practice and Problems of Transnational Counter-Terrorism (Cambridge University Press, 2021).

Rita Floyd is Associate Professor in Conflict and Security in the Department of Political Science and International Studies at the University of Birmingham, UK. In addition to the Morality of Security: A Theory of Just Securitization (Cambridge University Press, 2019), Floyd is the author of Security and the Environment: Securitisation Theory and US Environmental

${ }^{183}$ Helen Frowe, Defensive Killing (Oxford, UK: Oxford University Press, 2014). 
Security Policy (Cambridge University Press, 2010), as well as numerous articles mostly on securitisation theory and environmental security. Author's email: R.Floyd@bham.ac.uk

Ian Loader is Professor of Criminology at the University of Oxford, UK and Honorary Professorial Fellow in the School of Social and Political Sciences, University of Melbourne, Australia. Author’s email: ian.loader@crim.ox.ac.uk

Paul Roe is an Associate Professor in the Department of International Relations at Central European University, Vienna. His work has appeared in journals such as Security Studies; Security Dialogue; and Review of International Studies. He is also the author of Ethnic Violence and the Societal Security Dilemma (Routledge, 2005).

Jessica Wolfendale is Professor of Philosophy and Chair at Marquette University. Her primary research focuses on the ethics of political violence and the moral psychology of state-sponsored violence. She is the co-author of War Crimes: Causes, Excuses, and Blame (with Matthew Talbert, Oxford University Press 2018), and Torture and the Military Profession (Palgrave-Macmillan, 2007), and has published numerous articles and book chapters on terrorism, the ethics of torture, security, military ethics, and war crimes. She is currently working on a book project on torture and terrorism in America.

Cite this article: 2022. The morality of security: A theory of just securitisation. European Journal of International Security 7 , 248-282. https://doi.org/10.1017/eis.2022.3 